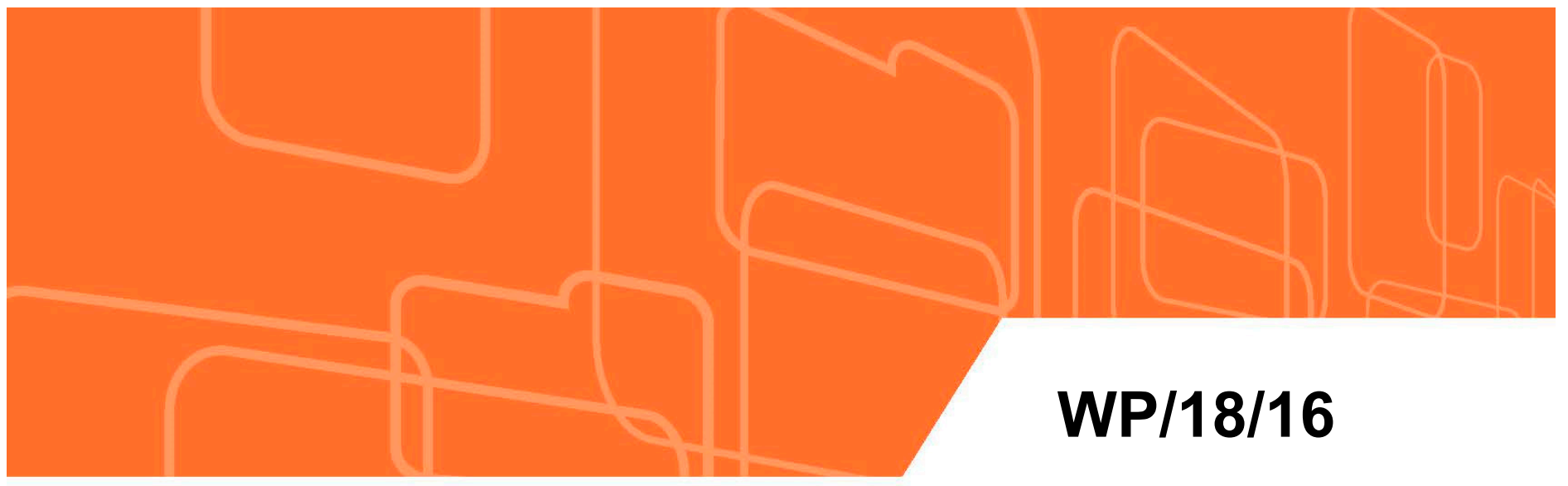

IMF Working Paper

\title{
New Estimates for Direction of Trade Statistics
}

by Marco Marini, Robert Dippelsman, and Michael Stanger

IMF Working Papers describe research in progress by the author(s) and are published to elicit comments and to encourage debate. The views expressed in IMF Working Papers are those of the author(s) and do not necessarily represent the views of the IMF, its Executive Board, or IMF management.

I N T ER N A T O N A L M O N E T A R Y F U N D 


\title{
IMF Working Paper
}

\author{
Statistics Department \\ New Estimates for Direction of Trade Statistics \\ Prepared by Marco Marini', Robert Dippelsman, and Michael Stanger \\ Authorized for distribution by Claudia Dziobek
}

January 2018

\section{IMF Working Papers describe research in progress by the author(s) and are published to elicit comments and to encourage debate. The views expressed in IMF Working Papers are those of the author(s) and do not necessarily represent the views of the IMF, its Executive Board, or IMF management.}

\begin{abstract}
In March 2017, the IMF published an upgrade of its Direction of Trade Statistics (DOTS) dataset. This paper documents the new methodology that has been developed to estimate missing observations of bilateral trade statistics on a monthly basis. The new estimation procedure is founded on a benchmarking method that produces monthly estimates based on official trade statistics by partner country reported at different times and frequencies. In this paper we describe the new estimation methodology. Additional data sources have also been incorporated. We also assess the impact of the new estimates on trade measurement in DOTS at global, regional, and country-specific levels. Finally, we suggest some developments of DOTS to strenghten its relevance for IMF bilateral and multilateral surveillance.

JEL Classification Numbers: C22, C61, C82

Keywords: Merchandise Trade, Benchmarking.

Author’s E-Mail Address: mmarini@imf.org; rdippelsman@imf.org; mstanger@imf.org

\footnotetext{
${ }^{1}$ We would like to thank Raja Hettiarachchi, Kenneth Kirkley, Wendy Mak, Laurent Meister, and Mesli Taha for their contribution and collaboration throughout the update project of DOTS. We are grateful to Jaebin Ahn, James Aylward, Benjamin Carton, Ruo Chen, Ricardo Davico, Cleary Haines, and Ezgi Ozturk for participating in a Fund-wide DOTS user group. Special thanks go to Benjamin Carton who provided detailed comments on an early draft of this paper. We are also grateful to our colleagues Messrs. Louis Marc Ducharme, Roberto Rosales, Gabriel Quiros, Claudia Dziobek, Andreas Hake, Patrizia Tumbarello, Ethan Weisman, Serkan Arslanalp for their support and suggestions. Finally, we extend our thanks to Fabienne Fortanier (OECD), Sophie Limpach (Eurostat), and Markie Muryawan (United Nations) for their cooperation in this project.
} 


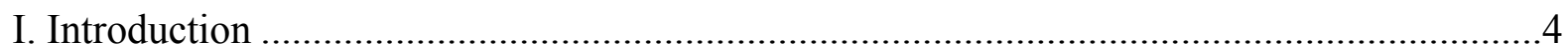

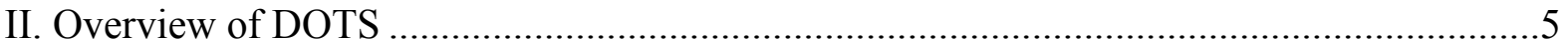

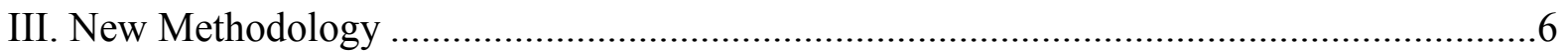

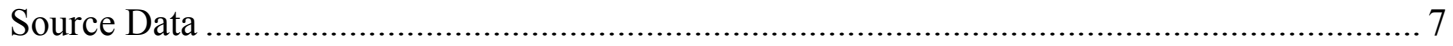

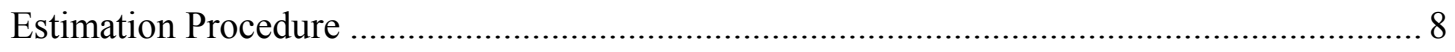

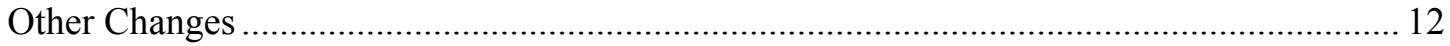

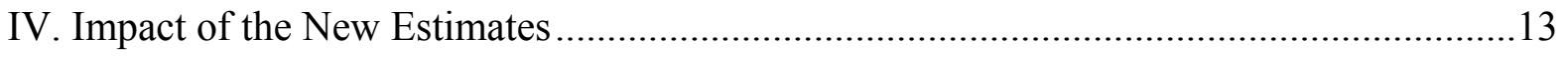

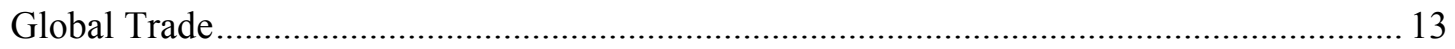

Advanced Economies vs Emerging and Developing Economies....................................... 14

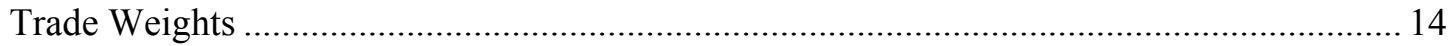

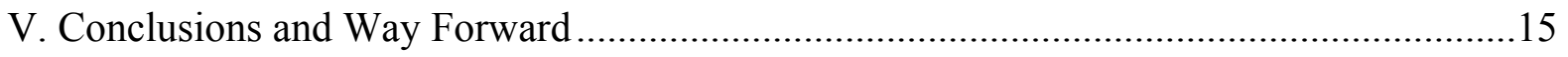

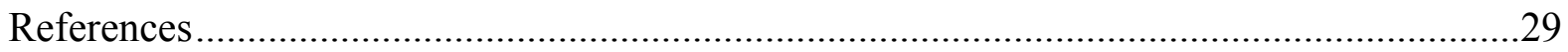

\section{Figures}

Figure 1. Type of Partner Countries in DOTS …............................................................. 18

Figure 2. DOTS: Distribution of Reported Data (Monthly and Annual) and Estimated Data 19

Figure 3. World Trade in DOTS obtained from UN COMTRADE ....................................19

Figure 4. Revisions to World Exports and Imports .......................................................20

Figure 5. Difference between World Imports and World Exports.........................................20

Figure 6. Trade Balance of Emerging and Developing Economies vs. Advanced Economies

Figure 7. Breakdown by Country Group of Trade Balance of Emerging and Developing Economies vs. Advanced Economies ........................................................................21

Figure 8. Global Trade: DOTS vs CPB World Trade Monitor..............................................22

Figure 9. Seasonal Adjustment of World Exports ..........................................................23

\section{Tables}

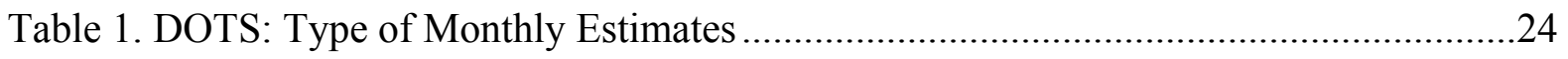

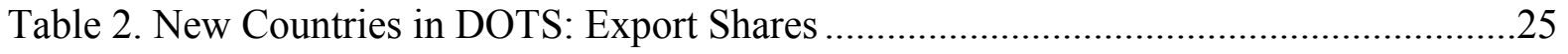

Table 3. New Countries in DOTS: Import Shares .........................................................26

Table 4. Countries with Largest Changes in Export Shares ..............................................27

Table 5. Countries with Largest Changes in Import Shares .............................................28

\section{Annex}

Annex 1. New List of Partner Countries.............................................................................. 30

Annex 2. The Cholette-Dagum Benchmarking Method ..................................................35 


\section{INTRODUCTION}

The Direction of Trade Statistics (DOTS) dataset publishes exports and imports of goods by partner economy at monthly, quarterly, and annual frequencies. ${ }^{2}$ DOTS comprise official data of trade by geographical breakdown reported by country authorities to the IMF, or collected by the IMF from official sources. Official data are complemented with estimated data for individual countries that report (or publish) trade statistics with a delay, or do not publish trade statistics by partner country at all. ${ }^{3}$ Estimates for these countries are based on data reported by their trading partners or, when these are also unavailable, on their total level of exports and imports.

The estimation of missing trade statistics based on counterpart trade and other information is a distinctive feature of DOTS. The worldwide coverage of trade (official and estimated) makes DOTS a unique product for users of international trade statistics. DOTS is an up-todate and comprehensive monthly monitor on global trade, inter-regional dynamics, and country-specific directions of trade. DOTS also provides estimates of total trade for late and non-reporting countries. The IMF regularly uses DOTS for external trade assessment in the context of bilateral and multilateral surveillance.

In March 2017, the IMF published an upgrade of DOTS. This upgrade was the result of an update project conducted by the IMF Statistics Department to streamline, standardize, and automate the steps of the DOTS production process (collection, estimation, aggregation, validation, and dissemination). This project has led to substantial improvements in the quality of DOTS:

- Increased use of official sources. Coverage of world trade using official sources has increased to about 97.9 percent for the year 2015 (from 92.0 percent prior to the upgrade). Two main factors contributed to this increase: an improved, streamlined collection system at the IMF, which makes it easier for countries to report their trade statistics; and an automated collection of official data from the United Nations (UN) COMTRADE database. Updates from COMTRADE are retrieved daily using a machine-to-machine technology and incorporated in the DOTS dataset at every monthly release.

\footnotetext{
${ }^{2}$ Publication of DOTS began in 1950 as a joint publication of the United Nations, World Bank, and the IMF. In May 1976, the IMF assumed sole responsibility for DOTS publication. DOTS can be accessed at data.imf.org/dot. Monthly and quarterly data are available starting 1960. Annual data are available starting 1947. Monthly estimates are computed from January 1981.

${ }^{3}$ The term "country", as used in DOTS, does not in all cases refer to a territorial entity that is a state as understood by international law and practice. The term also covers some non-sovereign territorial economies, for which statistical data are maintained and provided internationally on a separate and independent basis. In this paper, we use "country" and "economy" interchangeably.
} 
- Expanded geographical scope. The number of countries available in DOTS has risen to 210 (from 182, an increase of 28 countries). They include all 189 IMF member countries, $2 \mathrm{UN}$ member states that are not part of the IMF (Cuba, Democratic People's Republic of Korea), and 20 other states and non-sovereign entities. Only 20 countries out of 210 are estimated fully using counterpart information. The full list of partner countries (including former countries, areas not specified, and special categories) comprise 229 countries (see Annex I and Figure 1).

- Increased timeliness. DOTS is now available 85 days after the end of the reference month (before the upgrade, timeliness was four months). Every month, the full dataset is released on the data.imf.org \dot portal based an advanced release calendar schedule. Publication of updates are made around the $25^{\text {th }}$ of each month.

- Improved quality of estimates. A new methodology to estimate missing observations of bilateral trade statistics at the monthly level has been developed. The new estimates - starting January 2000 - substantially improve the accuracy and consistency of DOTS series.

In this paper we describe the new estimation methodology. The core method is the regression-based benchmarking model developed by Cholette and Dagum (2006), which is an ideal framework to combine official sources available at different frequencies. The benchmarking method is used to generate monthly estimates that are consistent with official annual data collected by the IMF, or available from other international organizations. Another fundamental change in the methodology is that monthly estimates of imports and exports are now derived by linking (or splicing) the month-to-month changes shown by the corresponding trade flows reported by partner countries, and not by using their levels adjusted for shipping and insurance costs. This splicing assumption - combined with the adoption of the Cholette-Dagum model - allows to obtain monthly estimates that are aligned with historical records of trade officially reported by individual countries, and avoids breaks in the level of the series caused by bilateral trade asymmetries.

The paper is structured as follows. Section II provides an overview of the DOTS dataset. Section III describes the new estimation methodology and other changes made in this upgrade. Section IV shows the impact of the new estimates on the DOTS aggregates. Finally, in Section V we outline a few developments of the DOTS dataset to strengthen its relevance for IMF bilateral and multilateral surveillance.

\section{OVERVIEW OF DOTS}

DOTS present, for all member countries of the IMF and a few non-member countries, the value of exports and imports of goods by partner economy. DOTS republish monthly, quarterly, annual trade statistics as submitted by countries to the IMF. Furthermore, reported data are supplemented by estimates whenever such data are not current or are not available 
monthly. Monthly estimates are consistent with quarterly and annual reported data, when available.

Data reported to DOTS follow the concepts and definitions of the UN International Merchandise Trade Statistics 2010 (IMTS 2010). IMTS 2010 provides the conceptual framework and guidance for recording physical movements of goods between countries and areas.

DOTS also include trade statistics collected by other international organizations. Monthly data for all European Union member countries are sourced from the COMEXT database maintained by EUROSTAT. Annual data reported to the UN COMTRADE database are used for those countries that do not report to the IMF. Furthermore, the availability of partner data makes it possible to calculate estimates of countries for which data are not obtainable from other sources. Further details on the integration of COMTRADE data and the estimation methodology are given in the next section.

Export and imports in DOTS have different valuations, consistent with the practice in most countries. Following the IMTS 2010 methodology, exports are recorded on free-on-board (FOB) basis and imports are recorded on cost, insurance, and freight (CIF) basis. Imports include shipping and insurance costs up to the border of the importing country, while exports exclude these costs. By construction, imports CIF reported by partner countries are expected to be larger than exports FOB.

In addition to difference in insurance and freight costs, there are several complications that can cause inconsistency between exports to a partner and the partner's recorded imports FOB, or between imports FOB from a partner and the partner's recorded exports. The main reasons for inconsistent statistics on destination and origin for a given shipment are differences in classification, time of recording, exchange rates movements, shipment and reexport through intermediate points (e.g., Amsterdam, Hong Kong), coverage, and processing errors. These asymmetries are not reconciled in the DOTS dataset. Official data by partner countries are published as reported.

\section{NEW MeTHodology}

The previous DOTS estimates were based on a methodology - developed in the early 1990s - based on partner country data, total trade, regional projections from the IMF World Economic Outlook, and trend extrapolations. The old methodology had several shortcomings, which led to time-series breaks in the estimated bilateral trade series and an excessive use of projections and trend extrapolations with little or no connection with actual trade developments. Further details about this methodology can be found in IMF (1993; section 3.2.1). 
The new DOTS methodology relies on an expanded set of official sources of bilateral trade statistics; a new estimation procedure to impute missing observations of bilateral trade statistics; and other improvements, such as a streamlined list of partner countries and a refined assumption for converting imports CIF into exports FOB (and vice versa).

Figure 2 shows the shares of reported and estimated data in DOTS for the year 2015. Monthly estimated data account for only 2.1 percent of world trade. However, these estimates are computed for over 13 thousand bilateral trade series (16 percent of the total number of partner combinations available in DOTS). The chart also shows that about 90 percent of world trade is covered by monthly official trade statistics reported to the IMF, and 8.3 percent by annual data. About 6 percent of the annual data are received from UN COMTRADE (see below).

\section{Source Data}

A major source of data is monthly reports, supplied by countries to the IMF Statistics Department. The number of countries reporting current monthly information to the IMF has increased substantially thanks to a streamlined report form and an increased effort of the IMF Statistics Department to reach out to non-reporting countries. At the time of writing, the monthly update of the DOTS database relies on 100 countries covering more than 90 percent of world trade. A status update of the current reporters is published every month in the "Documents" section of the DOTS portal (data.imf.org/dot; IMF, 2018a)The UN COMTRADE database is used as an official source to update DOTS. COMTRADE is the UN repository of international trade statistics. It contains detailed trade statistics reported by individual countries (or other non-sovereign territories) to the UN Statistics Division (UNSD). Data are expressed in US dollars (either reported or transformed by the UNSD), with details by product and by partner country. For DOTS, we only consider total bilateral trade statistics at the annual level with no product breakdown. ${ }^{4}$

COMTRADE provides access to a large collection of trade statistics. About 170 countries (or other territories) report trade statistics to the UNSD every year, covering more than 98 percent of world trade. This information is combined and integrated with official sources reported to the IMF. Figure 3 shows the share of world trade in DOTS sourced from COMTRADE. For 2015, COMTRADE data used in DOTS account for about 6 percent of world imports and 2.3 percent of world exports. In the previous methodology, this trade was estimated based on counterpart information or using assumptions based on past trends.

\footnotetext{
${ }^{4}$ The UNSD has also developed a monthly version of COMTRADE. However, country coverage of monthly statistics is still limited. The use of monthly COMTRADE as official source to update DOTS is left for future investigation. For a full description of the COMTRADE database, see the UN International Trade Statistics Knowledgebase (https://unstats.un.org/unsd/tradekb/Knowledgebase/.)
} 
In this update we have also strengthened the link between DOTS and COMEXT, the international trade statistics database of EU countries maintained by Eurostat. Monthly trade statistics for all $28 \mathrm{EU}$ countries are sourced from the dataset "DS-057380 EU Trade Since 1999 by HS2,4,6 and CN8", which is updated with official data reported by EU member countries to Eurostat. COMEXT is a monthly database released within 55 days the end of the reference month, therefore no estimation is required for EU countries at the time of the DOTS release. COMEXT is a key source for updating DOTS. COMEXT facilitates access to structured information for the 28 EU countries, which account for around 30 percent of world trade in recent years. ${ }^{5}$

The use of COMTRADE and COMEXT as official sources for DOTS will improve the consistency between international databases of trade statistics. Users of DOTS often send queries about inconsistencies identified with other databases (particularly, COMTRADE). Going forward, these inconsistencies are less likely to occur. COMEXT and DOTS are aligned at all times. For COMTRADE, monthly estimates in DOTS are consistent with annual data available in COMTRADE that are not reported to the IMF and to the UN.

\section{Estimation Procedure}

The new procedure for estimating missing monthly observations is based on three steps. First, gaps in monthly trade statistics for a country are filled using indicators that are related to the missing information: the "mirror" trade reported by the counterpart country, the total trade reported by the country, or the bilateral trade that other partner countries report against the missing country. Gaps are filled using a splicing approach, which preserves the shortterm movements of the chosen indicator.

In the second step, the monthly estimated data obtained in the first step are reconciled with official data reported at the monthly, quarterly, and annual frequency. The reconciliation process is made through a time-series benchmarking procedure that combines optimally (in a least-squares sense) the monthly estimates with official "benchmarks" reported by countries. After the second step, the sum of monthly estimates is consistent with official trade statistics available at the quarterly and annual frequency.

In the third and final step, bilateral trade series obtained in the second step (comprising both reported and estimated figures) are used to estimate bilateral trade for non-reporting countries. The three steps are explained in further detail below.

\footnotetext{
${ }^{5}$ COMEXT is based on the EU regulation on trade statistics, which differs from the UN IMTS 2010 (e.g., definition of country of origin, treatment of quasi-transit trade). For this reason, there could be differences between trade statistics of EU countries available in COMEXT and DOTS and those in COMTRADE, which are based on national definitions complying with IMTS 2010.
} 


\section{Step 1. Monthly Estimation of Missing Data}

Let us consider the bilateral trade of country $i$ with counterpart country $j$, where $i$ and $j$ can be any of the 210 countries currently available in DOTS (see Figure 1). In the first step, the procedure searches missing values of trade between $i$ and $j$ (as reported by $i$ ) and replaces them with estimates.

For country $i$, a missing value of exports to (or imports from) country $j$ exists for month $t$ when the following two conditions are met:

1. Country $i$ has reported trade with country $j$ for at least one period prior to month $t$, and

2. Country $i$ has not reported trade with other partner countries for month $t$.

An important implication of condition (2) is that when country $i$ reports trade with other partners but not with partner $j$, the bilateral trade between country $i$ and $j$ (from country $i$ 's perspective) is assumed to be nil. Missing data can be found (and estimates can be produced) only when a country does not report data by partner country for a specific month. A second consideration is that the existence of bilateral trade officially reported by country $i$ with country $j$ for past periods is a necessary condition to identify missing observations.

Let us assume that, for month $t$, there is a missing value for exports and imports of country $i$ vis-a-vis country $j$ (i.e., conditions 1 and 2 above are met). The new DOTS method will estimate this missing value using the following indicators, in order of priority:

1. Corresponding trade reported by counterpart country $j$ with country $i$ (i.e., mirror trade). For exports, the missing value is estimated using the value of imports from country $i$ reported by country $j$. For imports, the value of exports to country $i$ reported by country $j$ is used. The mirror trade approach was also used in the previous methodology. However, the new methodology uses a splicing approach in using the mirror trade. This avoids introducing breaks in the estimated series due to asymmetries between trade flows reported by partner countries. The assumption is that the missing trade co-moves with the corresponding flow reported by the counterpart country (e.g., if exports reported by country $j$ increases by 5 percent, the estimate of imports for country $i$ would also increase by 5 percent).

2. Total trade reported by country $i$. If the mirror trade is unavailable for month $t$ (indicator 1), the second-best indicator is the total value of exports (or imports) for month $t$ reported by country $i$ in the International Financial Statistics (IFS) database (IMF, 2018b). The IMF Statistics Department collects monthly data on total trade and publishes them in the IFS. Total trade statistics are received earlier than data by partner country, and country coverage is large (about 150 countries submit monthly total trade to the IFS on a regular basis). A splicing approach is also used with this 
indicator: the month-to-month change of total trade is used to estimate trade with counterpart country $j$ (and with any other partner country) for month $t$. The assumption with indicator 2 is that the geographical breakdown of month $t$ maintains the same structure of the latest observation by partner country received from the country.

3. Sum of trade reported by all other partner countries with country $i$. If country $i$ has not reported total trade statistics to the IFS for month $t$ (indicator 2), a proxy indicator of total trade for country $i$ is created using information from all partner countries reporting trade with country $i$. Indicator 3 is created as the sum of exports or imports for month $t$ reported by all partner countries with country $i$ (other than country $j$ ). Only the subset of countries that have reported trade with country $i$ on a continuous basis are included in this indicator. The month-to-month percent change calculated from this indicator is spliced to the missing bilateral trade series. This indicator is very convenient because it can be built using information available from current reporters, which are always available and accounts for about 90 percent of global trade.

As mentioned above, the new methodology uses a splicing approach to estimate the missing value of a trade flow. Let $y_{t}$ denote the missing value to be estimated, and $x_{t}$ the chosen indicator. The estimated value $\hat{y}_{t}$ is obtained as

$$
\hat{y}_{t}=y_{t-1} \cdot\left(\frac{x_{t}}{x_{t-1}}\right)
$$

In the previous methodology, estimates of missing data for reporting countries were obtained using a $\mathrm{CIF} / \mathrm{FOB}$ factor of 10 percent to convert reported exports and imports into the mirror trade. The splicing approach avoids the use of a CIF/FOB factor. A CIF/FOB assumption is still used to estimate bilateral trade series of non-reporting countries, as explained in Step 3.

\section{Step 2. Benchmarking Monthly Estimates to Quarterly and Annual Reported Data}

In step 2, the monthly estimates of step 1 are adjusted to be consistent with official quarterly and annual data reported by country $i$. Some countries report bilateral trade statistics to the IMF and to the UN only annually; a few countries also report quarterly data. Monthly estimates that are made consistent with quarterly and annual "benchmarks" are of superior quality, because they are "reconciled" with official data.

The benchmarking process - e.g., adjusting monthly data such that the sum of the adjusted figures is equal to quarterly and annual benchmarks - is done using the regression-based benchmarking model proposed by Cholette and Dagum (2006; see Annex 2 for a brief 
description). ${ }^{6}$ This model minimizes the impact of the adjustment on the short-term movements in the preliminary monthly series. The Cholette-Dagum framework can also produce backcasts and forecasts for months that are not covered by quarterly and annual benchmarks, taking into account the historical relationship between the monthly data and the quarterly and annual benchmarks.

The Cholette-Dagum method is applied only to bilateral trade flows with monthly estimates produced at step 1. Official monthly data are never benchmarked to overlapping official quarterly or annual data. Although the benchmarking methodology can also be used to remove inconsistencies between monthly, quarterly, and annual data reported by countries, we never adjust official data reported by country authorities. Inconsistencies between official data reported at different frequencies by the same countries may appear in the DOTS. When quarters or years are only partially covered by official monthly data, quarterly and annual official figures are used to complement the missing information so that the sum of reported and estimated figures is consistent with official quarterly and annual benchmarks.

\section{Step 3. Estimation of Non-Reporting Countries}

The objective of step 3 is to estimate bilateral trade of non-reporting countries based on data reported by (and estimated for) their partners. At the end of step 2, all missing values of bilateral trade for reporting countries are estimated and reconciled with available quarterly and annual benchmarks. No further step is needed for reporting countries after step 2 . However, reporting countries may show trade flows with some non-reporting countries (i.e., countries that have never reported or published trade statistics by partner country).

Exports and imports of non-reporting countries are estimated based on the assumption of symmetry with the values of imports and exports, respectively, declared by their counterpart countries. A CIF/FOB adjustment of 6 percent is used for non-reporting countries. The value of exports is equal to the value of imports from a partner divided by 1.06; the value of imports is equal to the value of exports multiplied by 1.06 (See "Other Changes" below, for further details on this $\mathrm{CIF} / \mathrm{FOB}$ factor.)

The publication of data for non-reporting countries in DOTS is new. Previously, estimates were only produced for reporting countries, namely for countries that have reported or published trade statistics by geographical breakdown for at least one period in the past. The new DOTS also include the estimated trade of non-reporting countries in the world and country group aggregates.

Table 1 shows the share of world trade derived using the different types of indicator for the year 2015. For estimates reconciled with annual benchmarks of reporting countries (steps 1 and 2), the indicator based on counterpart trade (indicator 1) accounts for 5 percent of world

\footnotetext{
${ }^{6}$ For further details on the benchmarking methodology, refer to Chapter 6 of the IMF's Quarterly National Accounts Manual - 2017 Edition (IMF, 2017).
} 
trade, total trade (indicator 2) for 1.8 percent, and other partners trade (indicator 3) for 1.4 percent. Monthly estimates for non-reporting countries (Step 3) are produced for 2.1 percent of world trade.

\section{Other Changes}

The new partner country list comprises 229 countries (Figure 1 and Annex 2). The number of partner countries has been reduced from more than 300 countries and territories, due to duplications, deceased countries, and a number of territories that are part of existing countries (e.g., Alaska for the U.S.). The new list is used in the IMF Integrated Correspondent System (ICS) report form for DOTS. The current list of 229 countries includes the 189 member countries of the IMF; 13 non-member countries; 9 non-sovereign entities; 6 areas not specified (one for the world, one for each country group); special categories; and 11 former countries (e.g., USSR).

The new list also defines start dates and end dates for each country. Validity dates are used only for the estimation of missing data. The methodology produces monthly estimates only for countries that exist in each month. However, validity dates are not used for official data reported by country authorities. If a country reports data with a partner that no longer exists, those data are treated as official data in the DOTS dataset.

As mentioned earlier, the new $\mathrm{CIF} / \mathrm{FOB}$ factor used for converting imports CIF into exports FOB (and vice versa) is 6 percent. Previously, the CIF/FOB factor used in the DOTS was 10 percent. The 6 percent assumption is based on the OECD International Transport and Insurance Costs (ITIC) database. Bilateral CIF/FOB margins at the product detail level are estimated based on a gravity-type model that uses explicit data on transportation and insurance costs (Miao and Fortanier, 2017). According to OECD calculations based on the ITIC database, the trade-weighted average of transportation and insurance costs for all countries over 1995-2014 is 6 percent of the CIF value (OECD, 2016). The assumption used in DOTS is based on this average. ${ }^{7}$

Finally, the new procedure clearly distinguishes missing trade (unreported) from zero trade (reported). Thanks to a thorough clean-up process in the historical series that removed all the zeroes in the reported dataset, missing values are distinguished from zero values. Before this update, zero values could indicate either missing trade or no trade due to different reporting practices of countries and data processing procedures implemented in the IMF. Zero values

\footnotetext{
${ }^{7}$ The ITIC database was released by the OECD in November 2016. Given the limited time available to review this database before the March 2017 release of DOTS, it was not possible to test the use of country-specific, time-varying CIF-FOB ratios estimated by the OECD. In the new methodology CIF/FOB ratios are used to estimate only non-reporting countries, which account for a very small share of world trade (less than 0.5 percent).
} 
have also been removed from the published dataset. If a bilateral trade flow is absent for a given period, it should be considered nil.

\section{IMPACT OF THE NEW ESTIMATES}

The new methodology produced revisions to previously published estimates due to the incorporation of official data (from COMTRADE or other official sources) or the calculation of improved estimates. This section presents a summary of the main changes caused by the new estimates on DOTS values at the global, regional, and country levels.

In the following comparisons, we indicate as "new" the DOTS data based on the new methodology published on March 1, 2017. The "old" data are those published in February 2017, based on the 1993 methodology (IMF, 1993). Revisions are assessed for annual data from 2000 to 2015 (which was the last full year available at the time of the March 2017 release).

\section{Global Trade}

The new methodology shows a reduction of world imports CIF, while the level of world exports FOB remained broadly unchanged (Figure 4). World imports have been revised down by an average of 0.31 percent per year during 2000-2015. The reduction of world imports, which is systematic from 2005, is due to two main reasons: (i) replacement of previous estimates with official data available in COMTRADE (see Figure 3 to note the larger impact of imports data); (ii) a lower CIF/FOB ratio (6 percent vs. previous 10 percent), which shifted downward the level of imports CIF for countries reporting imports on an FOB basis (e.g., Australia, Canada, Mexico). The increase of world exports for the years 20002003 is largely explained by a realignment with official sources for EU member countries available in COMEXT.

Due to the imports reduction, world exports and world imports are closer than before (Figure 5). The average 2000-2015 percent difference between imports and exports is 2.31 percent, compared with 2.69 percent in the old data. The distance between imports and exports over this period declines similarly, but does so at a faster pace than in the old data. A faster reduction of the world $\mathrm{CIF} / \mathrm{FOB}$ ratio is coherent with a declining trend observed in CIF/FOB ratios of individual countries (see Table 5 in Miao and Fortanier, 2017). The value of the implicit CIF/FOB ratio at the world level (around 1.5 percent in 2015) is far from the 6 percent weight estimated in the OECD ITIC database. However, an implicit CIF/FOB ratio is not an accurate measurement of world shipping and insurance costs because the underlying imports CIF and exports FOB data differ for several reasons, not only CIF and FOB valuations (e.g., timing, exchange rate movements, recording of special trade, general or special trade systems.) 


\section{Advanced Economies vs Emerging and Developing Economies}

The new estimates shows an improvement in the trade balance of emerging market and developing economies vis-à-vis advanced economies since 2000 (Figure 6). On average, the emerging market and developing economies trade balance with advanced economies during 2000-2015 has increased by USD 64 billion (or 15 percent of the previous level). This increase - which has grown over the years - is the result of an upward adjustment of exports to advanced economies and a downward adjustment of imports from advanced economies (partly as a result of the lower $\mathrm{CIF} / \mathrm{FOB}$ factor).

The breakdown by detailed country groups shows that the largest revisions come from the groups "Middle East, North Africa, and Pakistan" and "Western Hemisphere" (Figure 7). Starting 2005, more than 85 percent of the increase in the emerging market and developing economies trade balance is explained by better external trade positions of these two groups visà-vis advanced economies. In particular, the new estimates point towards an increase in the trade balance of oil-exporting countries in the Middle East.

\section{Trade Weights}

Export and import shares for the 28 new countries in DOTS are presented in Table 2 and 3, respectively. ${ }^{8}$ The data shown in the tables are average shares by country group for the period 2011-2015. ${ }^{9}$ For 16 countries, these shares are based on official annual data available in COMTRADE: Anguilla, Antigua and Barbuda, Bhutan, Botswana, Eritrea, French Polynesia, Kiribati, Lesotho, Micronesia, Montserrat, Namibia, Palau, Swaziland, Timor-Leste, Tuvalu, and West Bank and Gaza. For the remaining 12 countries, the shares are estimated based on counterpart trade data (see step 3 of the estimation procedure): American Samoa, Curacao, Falkland Islands, Gibraltar, Guam, Kosovo, Marshall Islands, Nauru, San Marino, Sint Maarten, South Sudan, and Vatican.

The 28 new countries in DOTS account for 0.12 percent of world exports and 0.30 percent of world imports during 2011-2015. Countries with large concentration of trade with individual partners are Bhutan (with India), Lesotho and Swaziland (with South Africa), San Marino and the Vatican (with Italy), and West Bank and Gaza (with Israel).

Countries with the largest changes in trade shares are shown in Table 4 and 5 (exports and imports, respectively). These countries are all emerging market and developing economies because estimates in DOTS are mostly produced within this group. The tables show the

\footnotetext{
${ }^{8}$ The group "Other" shown in Tables 1-4 comprise the following subgroups: Countries not included elsewhere (currently, Cuba and Democratic People's Republic of Korea), Special Categories, and Countries not specified.

${ }^{9}$ For space reasons, in this paper we present new and revised weights by country group. Weights by partner country are available on request.
} 
difference between the new and old shares by country group. Countries are sorted according to the share increase with advanced economies. For both exports and imports, revisions in the weights are due to the changes introduced in the new methodology: an increased use of official data available in COMTRADE and other sources (which replaced previous estimates), a splicing approach for the estimation of missing observations in lieu of the $\mathrm{CIF} / \mathrm{FOB}$ transformation, and the use of actual data from partner countries to replace pasttrend extrapolations.

\section{CONCLUSIONS AND WAY FORWARD}

The changes introduced in this update aim to satisfy better the user demand for timely, consistent, and comprehensive data on international trade. The automated links created with COMTRADE and COMEXT provide a real-time and continuous update of DOTS with information contained in the two databases (although differences may still arise if countries submit different numbers to different institutions). DOTS users have access to long and methodologically consistent series on trade for 210 economies, by far the largest coverage among international databases of trade statistics. The estimation procedure is designed to preserve the continuity of the series and to avoid breaks due to the asymmetries in trade statistics. Finally, the full dataset is released within 85 days the end of the current month, one month earlier than before.

The new estimation procedure is monitored and validated at every update of DOTS, and adjustments are implemented as needed. Further improvements that have been planned by the IMF Statistics Department include the backcasting for the period January 1981-December 1999 using the new methodology, and the use of country-specific, time varying CIF-FOB margins available in the OECD database in lieu of the flat 6 percent assumption currently used to obtain estimates for non-reporting countries.

DOTS is a key input for multilateral and bilateral surveillance in the IMF. For some developing economies, DOTS is the only source available on trade statistics by partner country. DOTS data are used to calculate trade weights, which are needed to compute Global Economic Environment (GEE) variables for all IMF member countries. DOTS data are also used to prepare analytical chapters of the IMF World Economic Outlook or Regional Economic Studies. With the improvements introduced, the use of DOTS in the IMF can be expanded even further along two directions:

- $\quad$ Monitor recent trends of global and regional trade. For the latest month published, coverage of world trade using official sources is always well above 90 percent. The remaining share is estimated using official sources, either from counterpart countries or from data on total trade. DOTS can provide an accurate and timely measurement of the monthly developments in global trade. The DOTS world trade series is coherent 
with the Centraal Planbureau (CPB) world trade series in nominal terms ${ }^{10}$, which is widely used to monitor global trade at the monthly level (see Figure 8; CPB, 2017). The partner-country detail (not available in the CPB dataset) and the wide coverage of countries available in DOTS can help identifying drivers of global and regional trade fluctuations.

- $\quad$ Cross-check quality of trade statistics using counterpart information. In DOTS, it is possible to derive total exports and imports for an individual country as declared by its partner countries. These data can be contrasted with the official trade statistics reported by that individual country. Quality issues may arise from this comparison. Official data by partner countries do not always provide a comprehensive accounting of total trade. Some countries may omit trade with some countries for confidentiality reasons. The presence of informal cross-border trade may underestimate the level of imports and exports in the official figures towards neighbor countries. Re-exports and re-imports may distort the trade balance with specific partners, especially when the same flows are not recorded symmetrically. IMF country teams may consider adjusting the official trade statistics in their baseline scenario when the differences with counterpart data are substantial and difficult to justify.

The importance of international trade in services raises the question of extension of DOTS to services. However, DOTS is underpinned by the detailed data on partner countries obtained in customs declarations, while no equivalent source exists for services data, so the availability of services data by partner country is much less developed than for goods. An extension of DOTS towards trade in services is left for future investigation.

The current DOTS can be strengthened further to provide more timely and more detailed information on trade dynamics. Two directions can be taken. First, the use of machine-tomachine technology to source official trade statistics from countries should be increased to reduce the time lag of collection. Trade statistics of the largest world importers and exporters (like China and the United States) are publicly available in less than two months on the national websites. There is room to cut the current timeliness of 85 days even further. One way is to use automated web services (which are growing worldwide) to download trade statistics into the DOTS database automatically, instead of waiting for countries to report their statistics to the IMF.

DOTS could also potentially be used to produce indicators of real trade growth in seasonally adjusted form. Currently, figures in DOTS are presented in nominal terms and unadjusted for seasonal effects. This presentation may hamper the assessment of ups and downs of global trade in real terms. For example, the remarkable slowdown in global trade during 2015 was due to a sharp decline in commodity prices. A price-volume decomposition of global trade in

\footnotetext{
${ }^{10}$ World Trade Monitor is produced by the Centraal Planbureau, also known as the Netherlands Bureau for Economic Policy Analysis (www.cpb.nl).
} 
DOTS during that period can provide insights into the real term effect of the commodity price slowdown. Real measures of trade can be obtained using exports and imports deflators from national accounts or price statistics

Seasonal adjustment can provide a decomposition of world exports and imports into timeseries components (Figure 9). ${ }^{11}$ The new series of world trade highlights an upward trend, seasonal effects, and cyclical movements linked to the global business cycle. Lower-thanaverage seasonal activity is recorded for January, February and August, while seasonal peaks are noted in March and October (see bottom chart of Figure 9). By removing these seasonal effects, seasonal adjustment would permit a better assessment of short-term movements in trade. To limit the computational burden, seasonal adjustment could be applied for world and country group aggregates only. Standard software for seasonal adjustment used in official statistics (e.g., X13-ARIMA-SEATS, TRAMO-SEATS) can be used to calculate seasonally adjusted series of DOTS.

\footnotetext{
${ }^{11}$ Seasonal adjustment has been performed using X-13-ARIMA-SEATS available in JDemetra+ (version 2.1). The results shown in Figure 4 are generated using built-in automatic identification procedures.
} 
Figure 1. Type of Partner Countries in DOTS

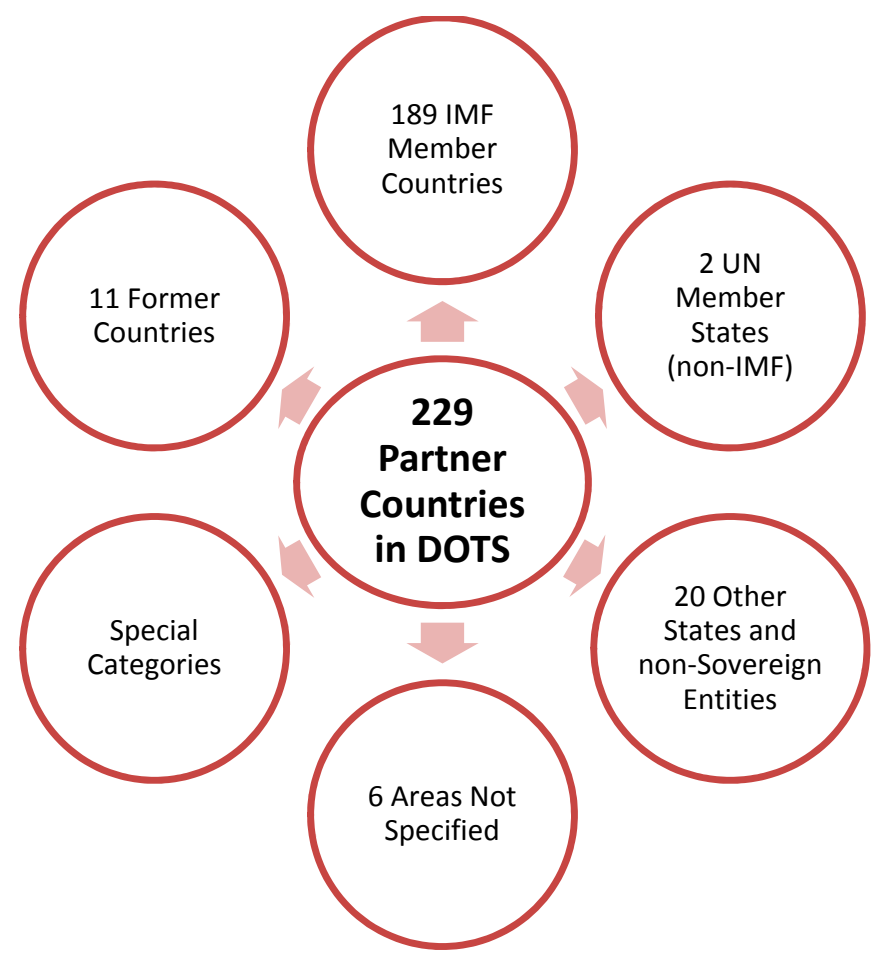


Figure 2. DOTS: Distribution of Reported Data (Monthly and Annual) and Estimated Data (Share of world trade (left) and percent of bilateral trade flows (right). Period: 2015.)
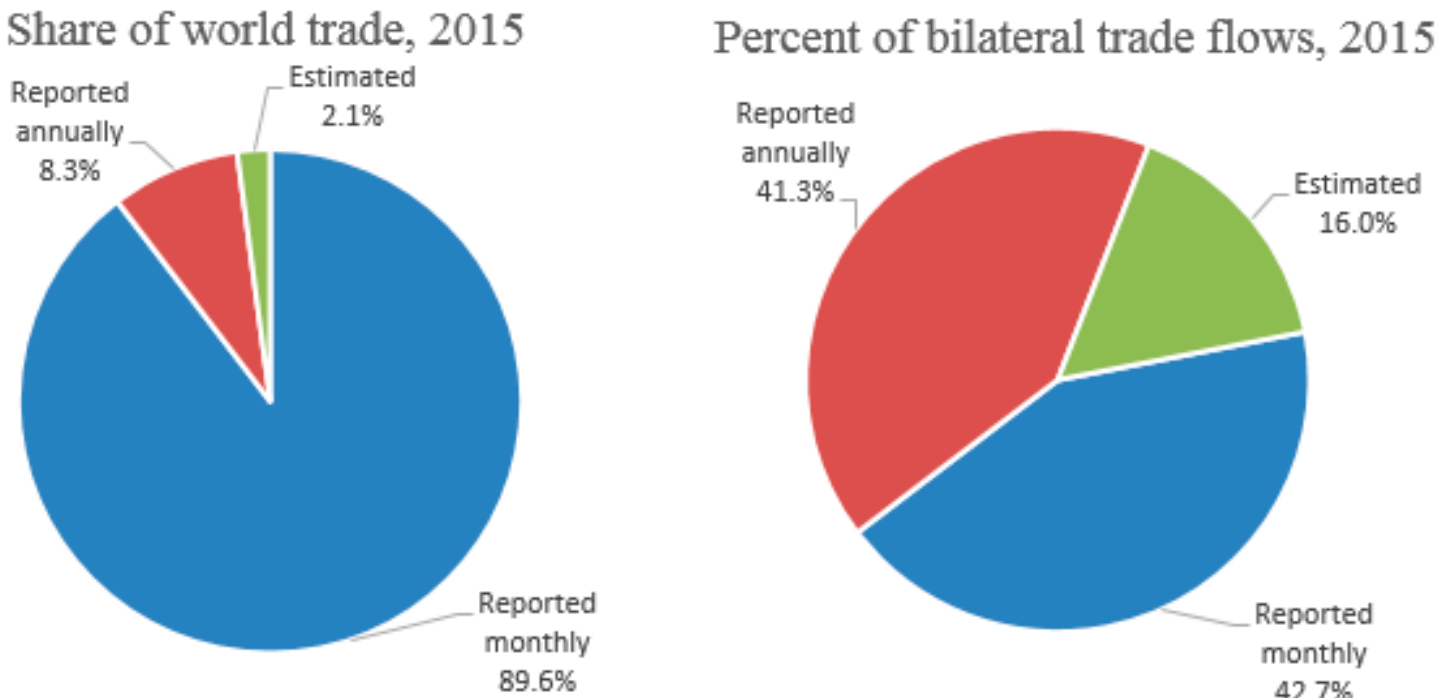

Source: DOTS.

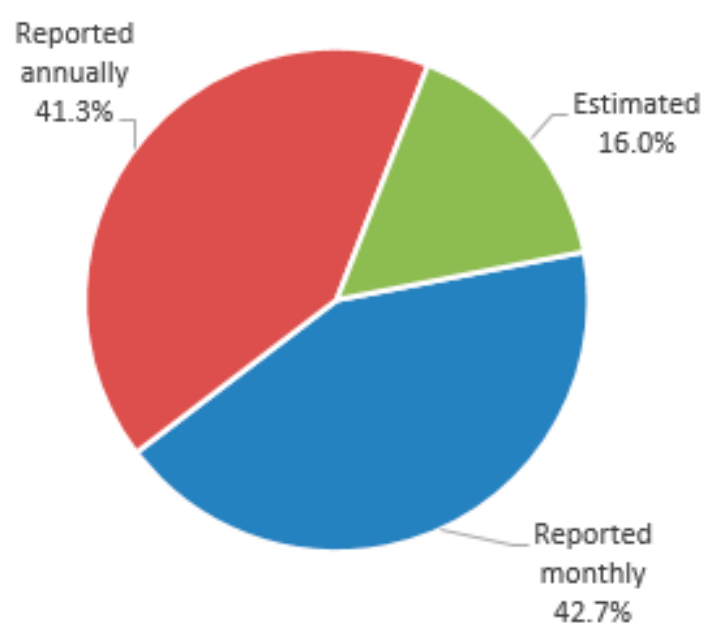

Figure 3. World Trade in DOTS obtained from UN COMTRADE (Percent. Period: 2000-2015.)

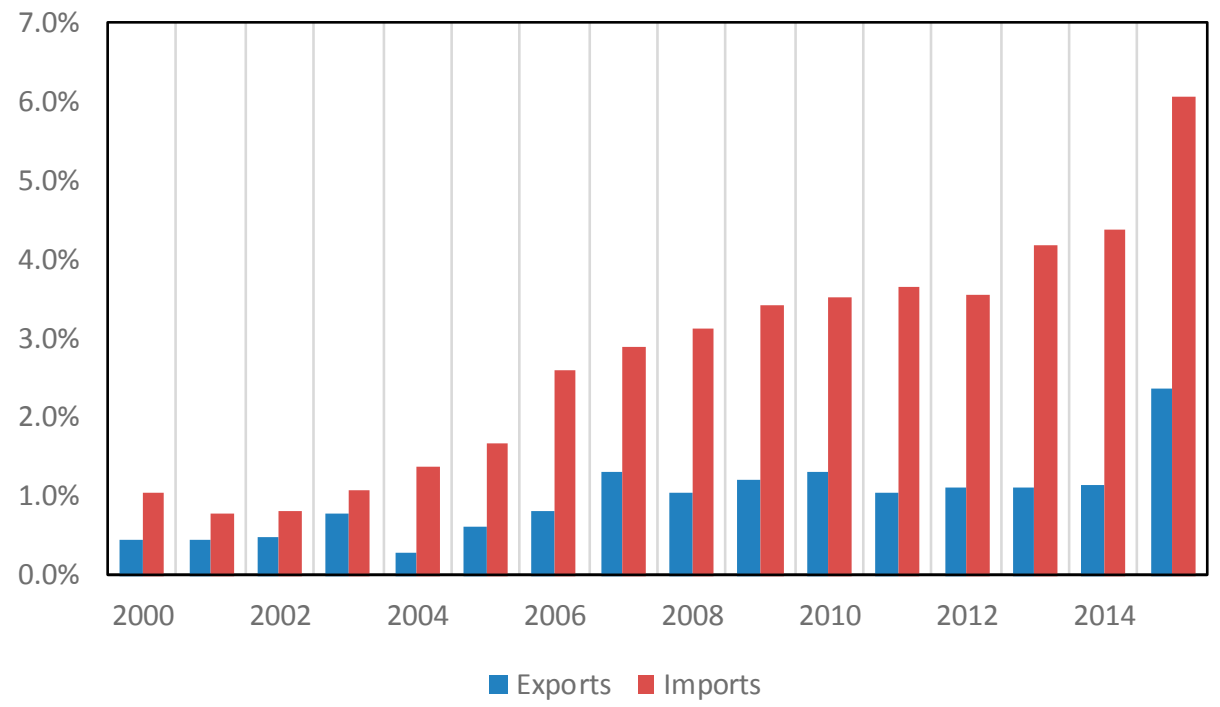

Source: DOTS. 
Figure 4. Revisions to World Exports and Imports (New - Old, in percent. Period: 2000-2015.)

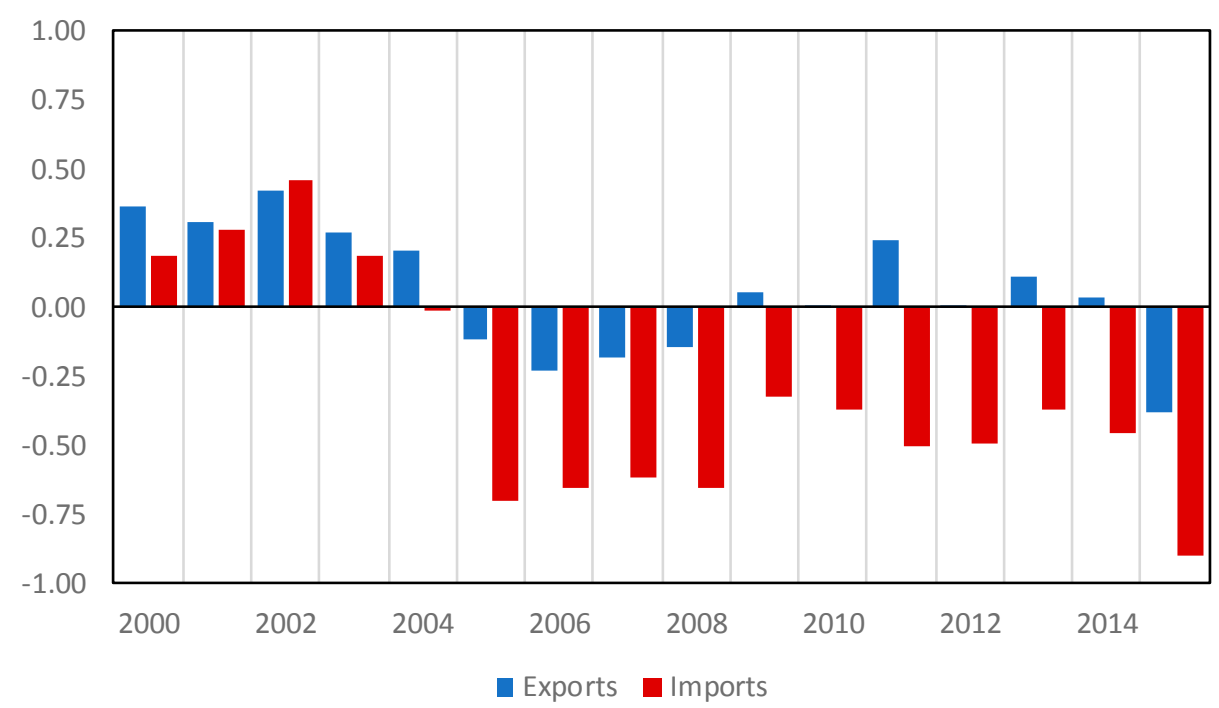

Source: DOTS.

Figure 5. Difference between World Imports and World Exports (In percent of World Exports. Period: 2000-2015.)

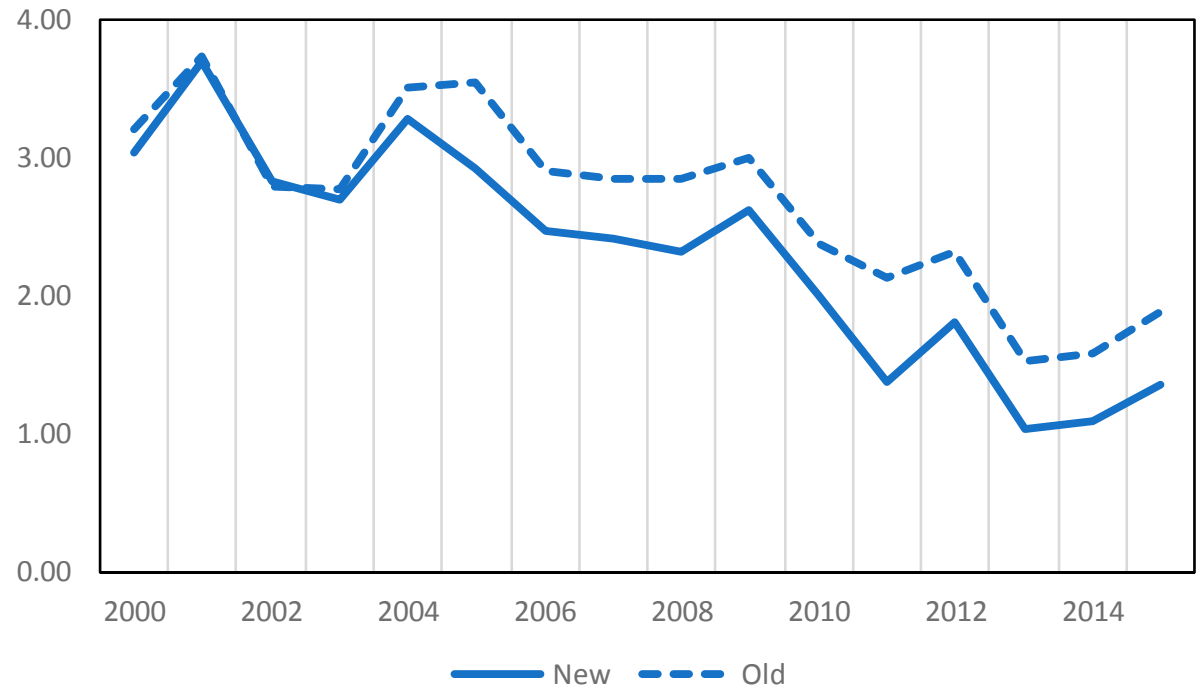

Source: DOTS. 
Figure 6. Trade Balance of Emerging and Developing Economies vs. Advanced Economies (Millions of US Dollars. Period: 2000-2015.)

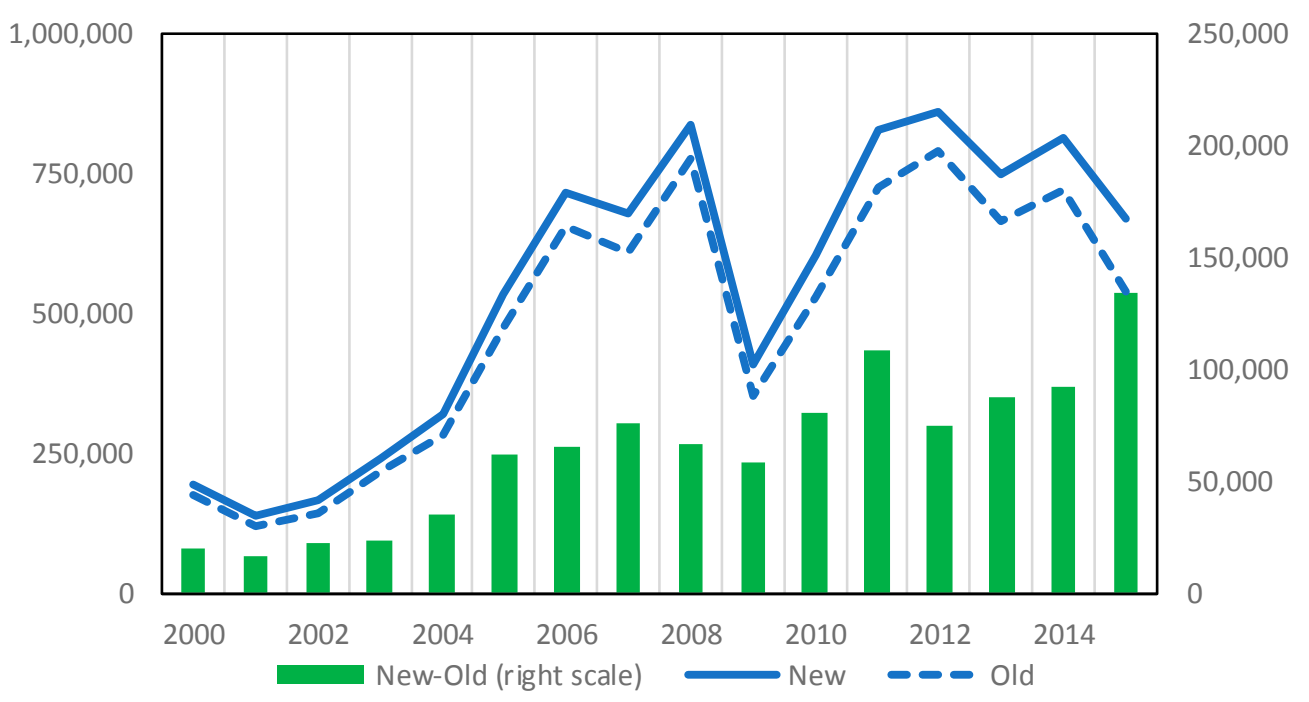

Source: DOTS.

Figure 7. Breakdown by Country Group of Trade Balance of Emerging and Developing Economies vs. Advanced Economies (Percent of World Trade Balance. Period: 2000-2015.)

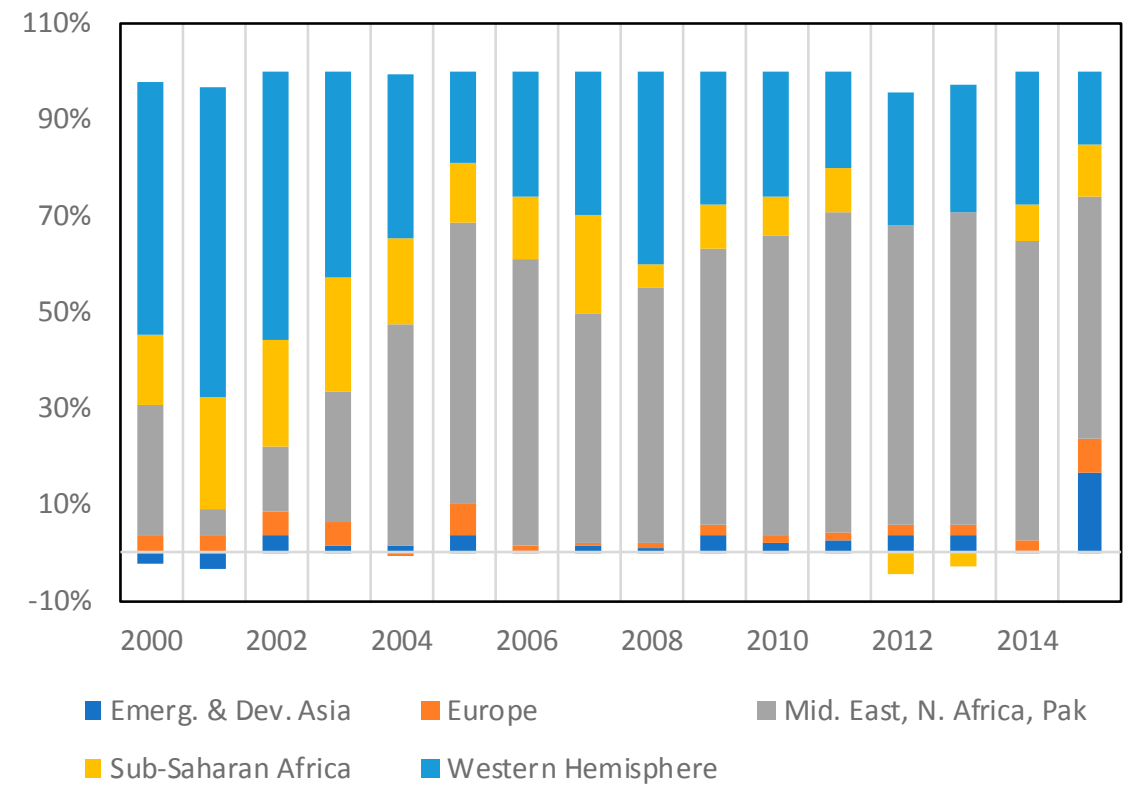

Source: DOTS. 
Figure 8. Global Trade: DOTS vs CPB World Trade Monitor (Index 2010=100. Period: January 2000-June 2017)

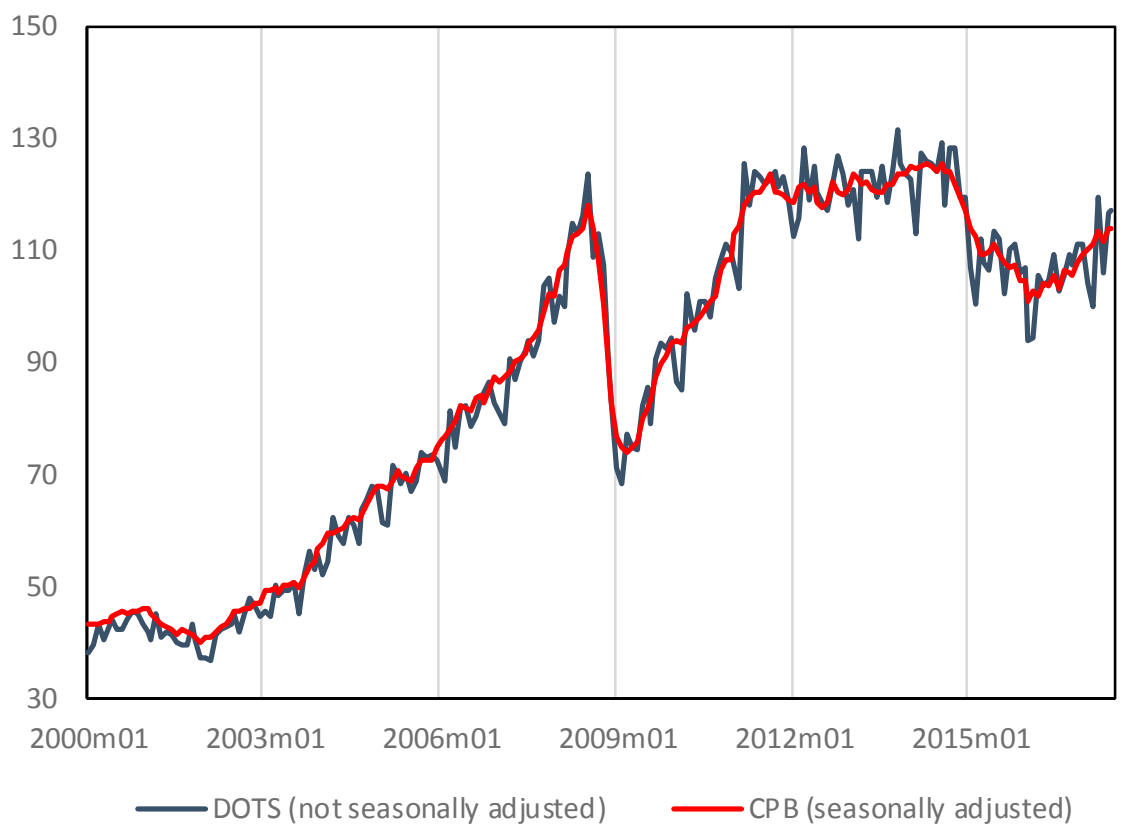

Source: DOTS, CPB World Trade Monitor. 
Figure 9. Seasonal Adjustment of World Exports

(Billions of USD. Period: January 2000-October 2016.)

Unadjusted and seasonal adjusted series

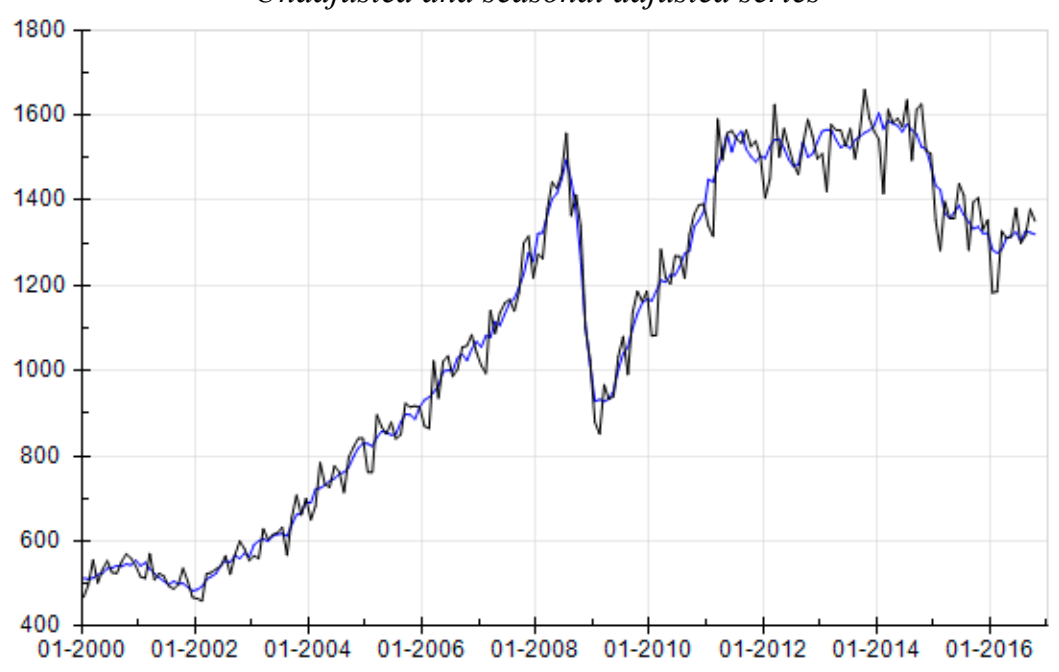

Seasonal factors

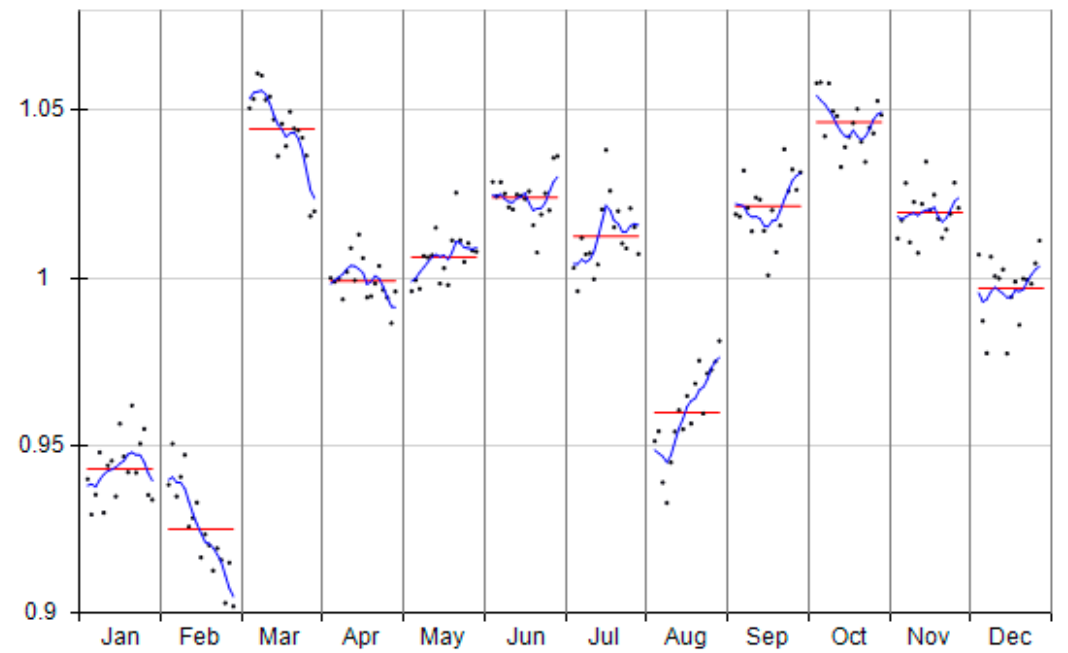

Source: DOTS, authors estimates. 
Table 1. DOTS: Type of Monthly Estimates

(Share of world trade and percent of bilateral trade flows. Period: 2015)

\begin{tabular}{|c|c|c|c|c|c|c|}
\hline \multirow[t]{2}{*}{ Type of Monthly Estimates in DOTS, year 2015} & \multicolumn{3}{|c|}{$\%$ of world trade } & \multicolumn{3}{|c|}{$\begin{array}{c}\% \text { of bilateral trade } \\
\text { flows }\end{array}$} \\
\hline & Exp & $\operatorname{Imp}$ & Tot & Exp & $\operatorname{Imp}$ & Tot \\
\hline Monthly estimates for reporting countries (Step 1 and 2) & 6.7 & 9.8 & 8.3 & 35.8 & 46.7 & 41.3 \\
\hline 1. Counterpart trade & 4.0 & 6.0 & 5.0 & 12.6 & 15.5 & 14.1 \\
\hline 2. Total trade & 1.6 & 2.0 & 1.8 & 12.8 & 16.7 & 14.8 \\
\hline 3. Other partners trade & 1.0 & 1.8 & 1.4 & 10.3 & 14.6 & 12.4 \\
\hline Monthly estimates for non-reporting countries (Step 3) & 3.5 & 0.6 & 2.1 & 21.0 & 11.1 & 16.0 \\
\hline
\end{tabular}


Table 2. New Countries in DOTS: Export Shares

(Percent of total exports. Period: 2011-2015 average.)

\begin{tabular}{|c|c|c|c|c|c|c|c|c|c|}
\hline \multirow[b]{2}{*}{ Country } & \multicolumn{9}{|c|}{ Export Shares (percent of country's total exports) } \\
\hline & $\begin{array}{l}\text { Advanced } \\
\text { Economies }\end{array}$ & $\begin{array}{l}\text { Euro } \\
\text { Area }\end{array}$ & $\begin{array}{c}\text { Emerging } \\
\text { \& Dev. } \\
\text { Economies }\end{array}$ & $\begin{array}{c}\text { Emerging } \\
\text { \& Dev. } \\
\text { Asia }\end{array}$ & Europe & $\begin{array}{c}\text { Mid } \\
\text { East, N } \\
\text { Africa, } \\
\text { Pak }\end{array}$ & $\begin{array}{c}\text { Sub- } \\
\text { Saharan } \\
\text { Africa }\end{array}$ & $\begin{array}{c}\text { Western } \\
\text { Hemisphere }\end{array}$ & Other \\
\hline American Samoa* & 42.8 & 0.8 & 57.2 & 21.2 & 2.8 & 2.4 & 19.5 & 11.3 & 0.0 \\
\hline Anguilla & 32.0 & 3.3 & 68.0 & 3.6 & 3.9 & 3.1 & 1.7 & 55.7 & 0.0 \\
\hline Antigua and Barbuda & 11.7 & 3.2 & 88.2 & 0.4 & 65.5 & 1.1 & 15.9 & 5.2 & 0.0 \\
\hline Bhutan & 6.0 & 2.2 & 94.0 & 93.8 & 0.1 & 0.0 & 0.1 & 0.1 & 0.0 \\
\hline Botswana & 68.7 & 13.9 & 31.3 & 8.3 & 0.0 & 2.3 & 20.7 & 0.0 & 0.0 \\
\hline Curacao* & 12.0 & 10.2 & 88.0 & 0.1 & 0.2 & 15.1 & 3.7 & 68.9 & 0.0 \\
\hline Eritrea & 25.9 & 2.7 & 74.1 & 53.6 & 2.1 & 15.2 & 1.0 & 2.2 & 0.0 \\
\hline F.T. French Polynesia & 74.6 & 13.5 & 25.4 & 4.9 & 18.3 & 0.0 & 0.1 & 2.0 & 0.0 \\
\hline Falkland Islands ${ }^{*}$ & 88.2 & 76.3 & 11.8 & 1.6 & 5.0 & 0.2 & 5.0 & 0.0 & 0.0 \\
\hline Gibraltar ${ }^{*}$ & 84.7 & 67.8 & 15.3 & 0.2 & 6.2 & 4.2 & 4.6 & 0.1 & 0.0 \\
\hline Guam* & 35.2 & 0.8 & 64.8 & 63.9 & 0.1 & 0.0 & 0.7 & 0.1 & 0.0 \\
\hline Kiribati & 25.2 & 0.1 & 74.8 & 46.6 & 0.0 & 28.2 & 0.0 & 0.0 & 0.0 \\
\hline Kosovo* & 58.8 & 53.6 & 41.2 & 0.0 & 41.2 & 0.0 & 0.0 & 0.0 & 0.0 \\
\hline Lesotho & 48.7 & 3.7 & 51.3 & 0.2 & 0.0 & 1.9 & 49.1 & 0.1 & 0.0 \\
\hline Marshall Islands & 27.5 & 26.1 & 72.5 & 0.1 & 51.9 & 3.2 & 14.3 & 2.9 & 0.0 \\
\hline Micronesia & 14.5 & 2.3 & 85.5 & 75.3 & 0.3 & 3.7 & 0.1 & 6.1 & 0.0 \\
\hline Montserrat & 46.7 & 21.4 & 52.3 & 2.9 & 0.3 & 4.9 & 2.4 & 41.8 & 0.0 \\
\hline Namibia & 48.4 & 16.9 & 51.6 & 3.5 & 0.4 & 0.2 & 45.6 & 1.9 & 0.0 \\
\hline Nauru ${ }^{*}$ & 60.8 & 0.4 & 39.2 & 16.2 & 0.3 & 0.7 & 21.4 & 0.6 & 0.0 \\
\hline Palau & 90.5 & 0.5 & 9.5 & 8.9 & 0.1 & 0.1 & 0.0 & 0.3 & 0.0 \\
\hline San Marino ${ }^{*}$ & 59.9 & 50.0 & 40.1 & 0.1 & 28.4 & 11.5 & 0.1 & 0.0 & 0.0 \\
\hline Sint Maarten ${ }^{*}$ & 45.0 & 31.0 & 55.0 & 0.0 & 1.3 & 0.0 & 0.0 & 53.7 & 0.0 \\
\hline South Sudan, Rep. of & 19.6 & 0.0 & 80.4 & 79.9 & 0.0 & 0.4 & 0.0 & 0.0 & 0.0 \\
\hline Swaziland & 5.2 & 4.3 & 94.8 & 1.2 & 1.7 & 1.5 & 90.2 & 0.3 & 0.0 \\
\hline Timor-Leste & 44.3 & 16.1 & 55.7 & 46.0 & 0.1 & 6.1 & 3.5 & 0.0 & 0.0 \\
\hline Tuvalu & 45.2 & 5.0 & 54.8 & 34.7 & 10.2 & 2.2 & 5.3 & 2.4 & 0.0 \\
\hline Vatican ${ }^{*}$ & 86.4 & 65.0 & 12.0 & 0.6 & 0.2 & 4.6 & 4.7 & 1.9 & 0.0 \\
\hline West Bank and Gaza & 87.9 & 1.3 & 12.1 & 0.1 & 0.4 & 11.6 & 0.0 & 0.0 & 0.0 \\
\hline
\end{tabular}

"For these countries, weights based on counterpart data only. 
Table 3. New Countries in DOTS: Import Shares

(Percent of total imports. Period: 2011-2015 average.)

\begin{tabular}{|c|c|c|c|c|c|c|c|c|c|}
\hline \multirow[b]{2}{*}{ Country } & \multicolumn{9}{|c|}{ Import Shares (percent of country's total imports) } \\
\hline & $\begin{array}{l}\text { Advanced } \\
\text { Economies }\end{array}$ & $\begin{array}{l}\text { Euro } \\
\text { Area }\end{array}$ & $\begin{array}{l}\text { Emerging } \\
\text { \& Dev. } \\
\text { Economies }\end{array}$ & $\begin{array}{c}\text { Emerging } \\
\text { \& Dev. } \\
\text { Asia }\end{array}$ & Europe & $\begin{array}{c}\text { Mid } \\
\text { East, } N \\
\text { Africa, } \\
\text { Pak }\end{array}$ & $\begin{array}{l}\text { Sub- } \\
\text { Saharan } \\
\text { Africa }\end{array}$ & $\begin{array}{c}\text { Western } \\
\text { Hemisphere }\end{array}$ & Other \\
\hline American Samoa* & 74.0 & 1.8 & 26.0 & 24.9 & 0.2 & 0.1 & 0.7 & 0.1 & 0.0 \\
\hline Anguilla & 78.8 & 10.1 & 21.2 & 0.7 & 0.2 & 0.1 & 0.4 & 19.7 & 0.0 \\
\hline Antigua and Barbuda & 48.8 & 3.9 & 20.8 & 6.0 & 0.3 & 0.1 & 0.3 & 14.2 & 30.4 \\
\hline Bhutan & 12.5 & 3.4 & 87.1 & 86.5 & 0.2 & 0.4 & 0.0 & 0.0 & 0.4 \\
\hline Botswana & 20.7 & 4.4 & 78.0 & 4.8 & 0.2 & 0.3 & 72.7 & 0.0 & 1.2 \\
\hline Curacao* & 37.8 & 32.6 & 62.2 & 46.5 & 1.4 & 0.3 & 3.8 & 10.2 & 0.0 \\
\hline Eritrea & 25.3 & 16.9 & 74.6 & 22.3 & 3.6 & 41.4 & 6.6 & 0.7 & 0.1 \\
\hline F.T. French Polynesia & 79.9 & 36.5 & 20.1 & 17.1 & 1.1 & 0.3 & 0.2 & 1.3 & 0.0 \\
\hline Falkland Islands* & 96.2 & 28.8 & 3.8 & 0.3 & 2.6 & 0.0 & 0.9 & 0.0 & 0.0 \\
\hline Gibraltar $^{*}$ & 86.1 & 53.3 & 13.9 & 4.1 & 8.9 & 0.4 & 0.4 & 0.1 & 0.0 \\
\hline Guam $^{*}$ & 93.4 & 3.9 & 6.6 & 4.9 & 1.5 & 0.0 & 0.0 & 0.1 & 0.0 \\
\hline Kiribati & 77.1 & 1.0 & 22.9 & 21.8 & 0.2 & 0.0 & 0.7 & 0.1 & 0.0 \\
\hline Kosovo* & 34.8 & 31.1 & 65.2 & 0.0 & 65.1 & 0.0 & 0.0 & 0.1 & 0.0 \\
\hline Lesotho & 6.8 & 0.6 & 93.2 & 7.1 & 0.0 & 0.2 & 85.8 & 0.0 & 0.0 \\
\hline Marshall Islands* & 71.8 & 64.4 & 28.2 & 0.3 & 27.6 & 0.0 & 0.3 & 0.0 & 0.0 \\
\hline Micronesia & 60.6 & 0.2 & 32.4 & 31.6 & 0.2 & 0.1 & 0.4 & 0.1 & 6.9 \\
\hline Montserrat & 82.8 & 2.8 & 17.1 & 0.6 & 0.0 & 0.3 & 0.1 & 16.1 & 0.1 \\
\hline Namibia & 17.9 & 5.1 & 79.8 & 6.6 & 1.2 & 0.5 & 69.1 & 2.5 & 2.3 \\
\hline Nauru* & 75.8 & 1.1 & 24.2 & 22.7 & 0.7 & 0.0 & 0.7 & 0.0 & 0.0 \\
\hline Palau & 72.0 & 1.1 & 28.0 & 27.8 & 0.0 & 0.0 & 0.0 & 0.2 & 0.0 \\
\hline San Marino* & 79.3 & 75.0 & 20.7 & 0.0 & 20.7 & 0.0 & 0.0 & 0.0 & 0.0 \\
\hline Sint Maarten & 58.9 & 50.4 & 41.1 & 0.0 & 0.5 & 0.0 & 3.7 & 36.9 & 0.0 \\
\hline South Sudan, Rep. of & 33.0 & 12.0 & 67.0 & 44.5 & 1.4 & 19.0 & 2.1 & 0.0 & 0.0 \\
\hline Swaziland & 2.3 & 0.5 & 97.7 & 18.4 & 0.0 & 0.4 & 77.8 & 1.0 & 0.0 \\
\hline Timor-Leste & 37.6 & 11.8 & 62.4 & 61.3 & 0.0 & 0.0 & 0.3 & 0.7 & 0.0 \\
\hline Tuvalu & 76.4 & 0.2 & 23.6 & 20.4 & 0.6 & 0.0 & 2.3 & 0.3 & 0.0 \\
\hline Vatican ${ }^{*}$ & 99.6 & 98.0 & 0.4 & 0.1 & 0.1 & 0.0 & 0.1 & 0.0 & 0.0 \\
\hline West Bank and Gaza & 80.9 & 7.8 & 19.1 & 6.5 & 6.9 & 4.7 & 0.2 & 0.8 & 0.0 \\
\hline
\end{tabular}

*For these countries, weights based on counterpart data only. 
Table 4. Countries with Largest Changes in Export Shares

(Difference New-Old, percent of total exports. Period: 2011-2015 average.)

\begin{tabular}{|c|c|c|c|c|c|c|c|c|c|}
\hline \multirow[b]{2}{*}{ Country } & \multicolumn{9}{|c|}{ Difference in Export Shares (New - Old, in percent of country's total exports) } \\
\hline & $\begin{array}{l}\text { Advanced } \\
\text { Economies }\end{array}$ & $\begin{array}{l}\text { Euro } \\
\text { Area }\end{array}$ & $\begin{array}{l}\text { Emerging } \\
\text { \& Dev. } \\
\text { Economies }\end{array}$ & $\begin{array}{c}\text { Emerging \& } \\
\text { Dev. Asia }\end{array}$ & Europe & $\begin{array}{l}\text { Mid East, } \\
\text { N Africa, } \\
\text { Pak }\end{array}$ & $\begin{array}{l}\text { Sub- } \\
\text { Saharan } \\
\text { Africa }\end{array}$ & $\begin{array}{c}\text { Western } \\
\text { Hemisphere }\end{array}$ & Other \\
\hline St. Lucia & 51.5 & 2.5 & -51.4 & 2.8 & 0.0 & 0.2 & 0.0 & -54.5 & 0.0 \\
\hline Samoa & 44.8 & -0.1 & -44.8 & -46.1 & 0.1 & 0.3 & 0.3 & 0.7 & 0.0 \\
\hline Grenada & 32.6 & 7.6 & -32.3 & -1.9 & 0.7 & 3.1 & -42.4 & 8.1 & -0.3 \\
\hline Papua New Guinea & 26.5 & 6.2 & -26.6 & 5.7 & -35.1 & 0.0 & 0.0 & 2.7 & 0.0 \\
\hline Central African Rep. & 25.5 & 22.2 & -25.5 & -17.8 & -2.2 & -3.2 & -2.2 & -0.1 & 0.0 \\
\hline Bahamas, The & 24.5 & 1.7 & -24.2 & -5.3 & -14.6 & -0.1 & 17.5 & -21.7 & -0.3 \\
\hline Gabon & 23.8 & 4.0 & -11.5 & -8.2 & -0.2 & 0.5 & 1.2 & -4.8 & -12.3 \\
\hline Fiji & 21.9 & 0.2 & 0.0 & -1.5 & 0.2 & 0.0 & 0.3 & 1.0 & -21.9 \\
\hline Barbados & 21.5 & -0.5 & -21.6 & 0.0 & -4.2 & 0.1 & -0.3 & -17.2 & 0.0 \\
\hline Tonga & 20.4 & -2.0 & -20.6 & -19.6 & -0.3 & 0.1 & 0.3 & -1.0 & 0.2 \\
\hline Kyrgyz Republic & 20.4 & 0.0 & -20.4 & -1.9 & -16.5 & -3.6 & 1.6 & 0.0 & 0.0 \\
\hline Myanmar & 14.6 & -0.5 & -13.3 & -10.7 & 0.1 & 0.3 & -2.7 & -0.4 & -1.3 \\
\hline Greenland & 12.0 & 3.4 & -7.8 & -9.0 & 1.7 & -0.8 & 0.4 & 0.0 & -4.2 \\
\hline Syrian Arab Republic & 12.0 & 9.8 & -12.0 & 5.3 & 9.7 & -28.1 & 0.2 & 0.8 & 0.0 \\
\hline Yemen, Republic of & -10.0 & 1.1 & 10.0 & 1.6 & 0.2 & 7.7 & 0.1 & 0.4 & 0.0 \\
\hline Sierra Leone & -10.3 & -5.1 & 10.6 & -14.0 & 8.0 & 6.0 & 9.8 & 0.6 & -0.3 \\
\hline Bosnia and Herzegovina & -10.6 & -8.9 & 10.6 & -0.7 & 10.8 & 0.5 & 0.0 & -0.1 & 0.0 \\
\hline Ethiopia & -11.0 & -1.1 & 11.0 & -12.6 & -0.9 & 25.2 & 0.2 & -0.9 & 0.0 \\
\hline St. Vincent \& Grens. & -11.6 & -9.9 & 11.5 & -1.5 & 2.1 & 0.0 & -2.9 & 13.9 & 0.0 \\
\hline Afghanistan, I.R. of & -13.5 & -5.1 & 13.5 & -3.7 & -8.1 & 24.7 & 0.6 & 0.1 & 0.0 \\
\hline São Tomé \& Príncipe & -14.1 & -8.0 & 14.0 & -0.4 & -3.1 & 0.4 & -0.8 & 17.9 & 0.0 \\
\hline Seychelles & -14.2 & -0.4 & 14.3 & -0.6 & -1.0 & 27.2 & -6.1 & -5.3 & -0.1 \\
\hline Gambia, The & -14.3 & -9.4 & 14.3 & -65.3 & 0.0 & -0.6 & 81.0 & -0.9 & 0.0 \\
\hline Mali & -15.5 & 1.3 & 19.5 & -26.8 & 5.6 & 3.8 & 37.2 & -0.2 & -4.1 \\
\hline Tajikistan & -15.5 & -6.1 & 15.5 & 16.7 & 3.6 & -5.0 & 0.0 & 0.3 & 0.0 \\
\hline Zimbabwe & -18.6 & -12.4 & 18.6 & -25.3 & -4.1 & 4.1 & 44.8 & -0.9 & 0.0 \\
\hline Ghana & -21.0 & -10.0 & 28.4 & -0.9 & -4.4 & 8.6 & 25.0 & 0.1 & -7.4 \\
\hline Dominica & -33.5 & 6.2 & 33.6 & 1.3 & 1.4 & 19.2 & 0.4 & 11.3 & -0.2 \\
\hline
\end{tabular}


Table 5. Countries with Largest Changes in Import Shares

(Difference New-Old, percent of total imports. Period: 2011-2015 average.)

\begin{tabular}{|c|c|c|c|c|c|c|c|c|c|}
\hline \multirow[b]{2}{*}{ Country } & \multicolumn{9}{|c|}{ Difference in Import Shares (New - Old, in percent of country's total imports) } \\
\hline & $\begin{array}{l}\text { Advanced } \\
\text { Economies }\end{array}$ & $\begin{array}{l}\text { Euro } \\
\text { Area }\end{array}$ & $\begin{array}{l}\text { Emerging } \\
\text { \& Dev. } \\
\text { Economies }\end{array}$ & $\begin{array}{c}\text { Emerging } \\
\text { \& Dev. } \\
\text { Asia }\end{array}$ & Europe & $\begin{array}{l}\text { Mid East, } \\
\text { N Africa, } \\
\text { Pak }\end{array}$ & $\begin{array}{l}\text { Sub- } \\
\text { Saharan } \\
\text { Africa }\end{array}$ & $\begin{array}{c}\text { Western } \\
\text { Hemisphere }\end{array}$ & Other \\
\hline St. Lucia & 45.3 & 6.5 & -45.3 & 2.0 & 0.1 & 0.0 & 0.0 & -47.3 & 0.0 \\
\hline Netherlands Antilles & 35.3 & 8.2 & -36.6 & 3.7 & 0.7 & -0.4 & 0.2 & -40.9 & 1.3 \\
\hline Tonga & 31.9 & -1.0 & -32.0 & -32.2 & 0.1 & 0.1 & 0.1 & -0.1 & 0.1 \\
\hline Guinea & 30.5 & 23.8 & -30.4 & 2.4 & 0.8 & 4.6 & 0.5 & -38.7 & -0.1 \\
\hline Bahamas, The & 29.7 & -2.5 & -28.8 & -15.9 & -3.8 & -1.1 & 0.4 & -8.3 & -0.9 \\
\hline St. Kitts and Nevis & 26.1 & -7.0 & -26.0 & 3.0 & -3.8 & -8.9 & 0.2 & -16.5 & -0.1 \\
\hline Vanuatu & 22.1 & 1.3 & -20.4 & -12.1 & -9.8 & 0.1 & 1.2 & 0.2 & -1.7 \\
\hline Grenada & 21.8 & 1.1 & -21.8 & 9.9 & 0.2 & -0.1 & 0.1 & -31.9 & 0.0 \\
\hline Djibouti & 21.6 & 21.7 & -20.2 & -37.6 & -1.0 & 15.1 & 3.8 & -0.6 & -1.4 \\
\hline Samoa & 20.4 & -0.2 & -19.6 & -18.4 & -0.3 & -0.3 & -0.1 & -0.5 & -0.8 \\
\hline Myanmar & 18.0 & 0.2 & -17.5 & -20.2 & -0.7 & 3.2 & 0.0 & 0.0 & -0.5 \\
\hline Barbados & 11.0 & 1.9 & -10.9 & 1.6 & -7.4 & 0.0 & 0.0 & -5.2 & -0.1 \\
\hline Kyrgyz Republic & 10.6 & 3.3 & -10.6 & -30.1 & 19.1 & 0.2 & 0.0 & 0.2 & 0.0 \\
\hline Syrian Arab Republic & 10.6 & 5.0 & -11.0 & 5.7 & 28.0 & -46.6 & 0.0 & 1.8 & 0.5 \\
\hline Tanzania & 10.1 & -0.3 & -10.2 & -18.9 & -2.1 & 9.6 & 1.0 & 0.2 & 0.0 \\
\hline Yemen, Republic of & 9.5 & 1.1 & -12.2 & -5.2 & 2.4 & -11.6 & -0.1 & 2.3 & 2.8 \\
\hline Belize & -4.2 & -8.2 & 13.4 & 5.6 & -3.9 & 0.2 & -0.1 & 11.7 & -9.2 \\
\hline Mali & -4.3 & -4.7 & 14.9 & 3.1 & 0.7 & 1.6 & 7.4 & 2.2 & -10.6 \\
\hline Sierra Leone & -9.0 & -5.5 & 13.1 & -17.7 & -3.4 & 8.3 & 30.1 & -4.3 & -4.0 \\
\hline Congo, Republic of & -10.0 & -6.9 & 10.3 & -15.5 & -1.9 & -0.5 & 29.8 & -1.6 & -0.3 \\
\hline São Tomé \& Príncipe & -12.0 & -11.2 & 12.0 & -3.4 & -0.9 & 1.2 & 15.4 & -0.4 & 0.0 \\
\hline Bahrain, Kingdom of & -12.4 & -4.2 & 3.1 & -0.9 & 0.0 & 2.9 & 0.4 & 0.8 & 9.2 \\
\hline Kazakhstan & -13.2 & -7.3 & 13.2 & -11.0 & 25.3 & -0.3 & -0.2 & -0.6 & 0.0 \\
\hline Trinidad and Tobago & -13.6 & -1.6 & 13.7 & 0.7 & -2.2 & 0.1 & 14.6 & 0.5 & -0.1 \\
\hline Faroe Islands & -18.3 & 9.6 & 18.8 & 11.7 & 2.2 & 0.1 & 0.1 & 4.6 & -0.5 \\
\hline Afghanistan, I.R. of & -19.8 & -4.7 & -14.1 & -1.3 & -12.1 & 1.3 & -1.9 & 0.0 & 33.9 \\
\hline
\end{tabular}




\section{References}

Centraal Planbureau (2017), CPB World Trade Monitor October 2017, available at https://www.cpb.nl/en/figure/cpb-world-trade-monitor-october-2017.

Denton, F. (1971), “Adjustment of Monthly or Quarterly Series to Annual Totals: An Approach based on Quadratic Minimization," Journal of the American Statistical Association, Vol. 66, pp. 99-102.

Dagum, E.B., and P.A. Cholette (2006), Benchmarking, Temporal Disaggregation, and Reconciliation Methods for Time Series, Springer edition.

Di Fonzo, T., and M. Marini (2012), “On the Extrapolation with the Denton Proportional Benchmarking Method,” IMF Working Paper Series, WP/12/169.

IMF (1993), “A Guide to Direction of Trade Statistics,” International Monetary Fund.

IMF (2017), Quarterly National Accounts Manual - 2017 Edition, International Monetary Fund, available at http://www.imf.org/external/pubs/ft/qna.

IMF (2018a), Direction of Trade Statistics, http://data.imf.org/DOT.

IMF (2018b), International Financial Statistics, http://data.imf.org/IFS.

OECD (2016), "New OECD database on International Transport and Insurance Costs," Statistical Insights, November 2016, available at http://oecdinsights.org/2016/11/02/statistical-insights-new-oecd-database-oninternational-transport-and-insurance-costs/.

Miao, G and F. Fortanier (2017), "Estimating Transport and Insurance Costs of International Trade ," OECD Working Paper, No. 2017/04.

United Nations (2011), International Merchandise Trade Statistics: Concepts and Definitions 2010, New York: United States. 
Annex 1. New List of Partner Countries

\begin{tabular}{|c|c|c|c|c|c|}
\hline N. & Country Name & $\begin{array}{l}\text { Start } \\
\text { Year }\end{array}$ & $\begin{array}{r}\text { Start } \\
\text { Month }\end{array}$ & $\begin{array}{l}\text { End } \\
\text { Year }\end{array}$ & $\begin{array}{r}\text { End } \\
\text { Month }\end{array}$ \\
\hline 1 & Afghanistan, Islamic Republic of & & & & \\
\hline 2 & Africa not specified & & & & \\
\hline 3 & Albania & & & & \\
\hline 4 & Algeria & & & & \\
\hline 5 & American Samoa & & & & \\
\hline 6 & Angola & & & & \\
\hline 7 & Anguilla & & & & \\
\hline 8 & Antigua and Barbuda & & & & \\
\hline 9 & Argentina & & & & \\
\hline 10 & Armenia, Republic of & 1992 & 1 & & \\
\hline 11 & Aruba & & & & \\
\hline 12 & Asia not specified & & & & \\
\hline 13 & Australia & & & & \\
\hline 14 & Austria & & & & \\
\hline 15 & Azerbaijan, Republic of & 1992 & 1 & & \\
\hline 16 & Bahamas, The & & & & \\
\hline 17 & Bahrain, Kingdom of & & & & \\
\hline 18 & Bangladesh & & & & \\
\hline 19 & Barbados & & & & \\
\hline 20 & Belarus & 1992 & 1 & & \\
\hline 21 & Belgium & 1997 & 1 & & \\
\hline 22 & Belgium-Luxembourg & & & 1996 & 12 \\
\hline 23 & Belize & & & & \\
\hline 24 & Benin & & & & \\
\hline 25 & Bermuda & & & & \\
\hline 26 & Bhutan & & & & \\
\hline 27 & Bolivia & & & & \\
\hline 28 & Bosnia and Herzegovina & 1993 & 1 & & \\
\hline 29 & Botswana & & & & \\
\hline 30 & Brazil & & & & \\
\hline 31 & Brunei Darussalam & & & & \\
\hline 32 & Bulgaria & & & & \\
\hline 33 & Burkina Faso & & & & \\
\hline 34 & Burundi & & & & \\
\hline 35 & Cabo Verde & & & & \\
\hline 36 & Cambodia & & & & \\
\hline 37 & Cameroon & & & & \\
\hline 38 & Canada & & & & \\
\hline 39 & Central African Republic & & & & \\
\hline 40 & Chad & & & & \\
\hline 41 & Chile & & & & \\
\hline 42 & China, P.R.: Mainland & & & & \\
\hline 43 & China, P.R.: Hong Kong & & & & \\
\hline 44 & China, P.R.: Macao & & & & \\
\hline 45 & Colombia & & & & \\
\hline 46 & Comoros & & & & \\
\hline 47 & Congo, Democratic Republic of & & & & \\
\hline 48 & Congo, Republic of & & & & \\
\hline
\end{tabular}




\begin{tabular}{|c|c|c|c|c|c|}
\hline N. & Country Name & $\begin{array}{l}\text { Start } \\
\text { Year }\end{array}$ & $\begin{array}{r}\text { Start } \\
\text { Month }\end{array}$ & $\begin{array}{l}\text { End } \\
\text { Year }\end{array}$ & $\begin{array}{r}\text { End } \\
\text { Month }\end{array}$ \\
\hline 49 & Costa Rica & & & & \\
\hline 50 & Cote d'Ivoire & & & & \\
\hline 51 & Countries \& Areas not specified & & & & \\
\hline 52 & Croatia & 1993 & 1 & & \\
\hline 53 & Cuba & & & & \\
\hline 54 & Curacao & 2010 & 11 & & \\
\hline 55 & Cyprus & & & & \\
\hline 56 & Czech Republic & 1993 & 1 & & \\
\hline 57 & Czechoslovakia & & & 1992 & 12 \\
\hline 58 & Denmark & & & & \\
\hline 59 & Djibouti & & & & \\
\hline 60 & Dominica & & & & \\
\hline 61 & Dominican Republic & & & & \\
\hline 62 & East Germany & & & 1990 & 6 \\
\hline 63 & Ecuador & & & & \\
\hline 64 & Egypt & & & & \\
\hline 65 & El Salvador & & & & \\
\hline 66 & Equatorial Guinea & & & & \\
\hline 67 & Eritrea & & & & \\
\hline 68 & Estonia & 1992 & 1 & & \\
\hline 69 & Ethiopia & & & & \\
\hline 70 & Europe not specified & & & & \\
\hline 71 & Falkland Islands & & & & \\
\hline 72 & Faroe Islands & & & & \\
\hline 73 & Fiji & & & & \\
\hline 74 & Finland & & & & \\
\hline 75 & France & & & & \\
\hline 76 & French Territories: French Polynesia & & & & \\
\hline 77 & French Territories: New Caledonia & & & & \\
\hline 78 & Gabon & & & & \\
\hline 79 & Gambia, The & & & & \\
\hline 80 & Georgia & 1992 & 1 & & \\
\hline 81 & Germany & & & & \\
\hline 82 & Ghana & & & & \\
\hline 83 & Gibraltar & & & & \\
\hline 84 & Greece & & & & \\
\hline 85 & Greenland & & & & \\
\hline 86 & Grenada & & & & \\
\hline 87 & Guam & & & & \\
\hline 88 & Guatemala & & & & \\
\hline 89 & Guinea & & & & \\
\hline 90 & Guinea-Bissau & & & & \\
\hline 91 & Guyana & & & & \\
\hline 92 & Haiti & & & & \\
\hline 93 & Honduras & & & & \\
\hline 94 & Hungary & & & & \\
\hline 95 & Iceland & & & & \\
\hline 96 & India & & & & \\
\hline 97 & Indonesia & & & & \\
\hline 98 & Iran, Islamic Republic of & & & & \\
\hline 99 & Iraq & & & & \\
\hline
\end{tabular}




\begin{tabular}{|c|c|c|c|c|c|}
\hline N. & Country Name & $\begin{array}{l}\text { Start } \\
\text { Year }\end{array}$ & $\begin{array}{r}\text { Start } \\
\text { Month }\end{array}$ & $\begin{array}{l}\text { End } \\
\text { Year }\end{array}$ & $\begin{array}{r}\text { End } \\
\text { Month }\end{array}$ \\
\hline 100 & Ireland & & & & \\
\hline 101 & Israel & & & & \\
\hline 102 & Italy & & & & \\
\hline 103 & Jamaica & & & & \\
\hline 104 & Japan & & & & \\
\hline 105 & Jordan & & & & \\
\hline 106 & Kazakhstan & 1992 & 1 & & \\
\hline 107 & Kenya & & & & \\
\hline 108 & Kiribati & & & & \\
\hline 109 & Korea, Democratic People's Rep. of & & & & \\
\hline 110 & Korea, Republic of & & & & \\
\hline 111 & Kosovo, Republic of & 2002 & 5 & & \\
\hline 112 & Kuwait & & & & \\
\hline 113 & Kyrgyz Republic & 1992 & 1 & & \\
\hline 114 & Lao People's Democratic Republic & & & & \\
\hline 115 & Latvia & 1992 & 1 & & \\
\hline 116 & Lebanon & & & & \\
\hline 117 & Lesotho & & & & \\
\hline 118 & Liberia & & & & \\
\hline 119 & Libya & & & & \\
\hline 120 & Lithuania & 1992 & 1 & & \\
\hline 121 & Luxembourg & 1997 & 1 & & \\
\hline 122 & Macedonia, FYR & 1993 & 1 & & \\
\hline 123 & Madagascar & & & & \\
\hline 124 & Malawi & & & & \\
\hline 125 & Malaysia & & & & \\
\hline 126 & Malaysia, West & & & 1963 & 8 \\
\hline 127 & Maldives & & & & \\
\hline 128 & Mali & & & & \\
\hline 129 & Malta & & & & \\
\hline 130 & Marshall Islands, Republic of & & & & \\
\hline 131 & Mauritania & & & & \\
\hline 132 & Mauritius & & & & \\
\hline 133 & Mexico & & & & \\
\hline 134 & Micronesia, Federated States of & & & & \\
\hline 135 & Middle East not specified & & & & \\
\hline 136 & Moldova & 1992 & 1 & & \\
\hline 137 & Mongolia & & & & \\
\hline 138 & Montenegro & 2006 & 6 & & \\
\hline 139 & Montserrat & & & & \\
\hline 140 & Morocco & & & & \\
\hline 141 & Mozambique & & & & \\
\hline 142 & Myanmar & & & & \\
\hline 143 & Namibia & & & & \\
\hline 144 & Nauru & & & & \\
\hline 145 & Nepal & & & & \\
\hline 146 & Netherlands & & & & \\
\hline 147 & Netherlands Antilles & & & & \\
\hline 148 & New Zealand & & & & \\
\hline 149 & Nicaragua & & & & \\
\hline 150 & Niger & & & & \\
\hline
\end{tabular}




\begin{tabular}{|c|c|c|c|c|c|}
\hline N. & Country Name & $\begin{array}{l}\text { Start } \\
\text { Year }\end{array}$ & $\begin{array}{r}\text { Start } \\
\text { Month }\end{array}$ & $\begin{array}{l}\text { End } \\
\text { Year }\end{array}$ & $\begin{array}{r}\text { End } \\
\text { Month }\end{array}$ \\
\hline 151 & Nigeria & & & & \\
\hline 152 & North Vietnam & & & 1975 & 12 \\
\hline 153 & Norway & & & & \\
\hline 154 & Oman & & & & \\
\hline 155 & Pakistan & & & & \\
\hline 156 & Palau & & & & \\
\hline 157 & Panama & & & & \\
\hline 158 & Papua New Guinea & & & & \\
\hline 159 & Paraguay & & & & \\
\hline 160 & Peru & & & & \\
\hline 161 & Philippines & & & & \\
\hline 162 & Poland & & & & \\
\hline 163 & Portugal & & & & \\
\hline 164 & Qatar & & & & \\
\hline 165 & Romania & & & & \\
\hline 166 & Russian Federation & 1992 & 1 & & \\
\hline 167 & Rwanda & & & & \\
\hline 168 & Samoa & & & & \\
\hline 169 & San Marino & & & & \\
\hline 170 & Sao Tome and Principe & & & & \\
\hline 171 & Saudi Arabia & & & & \\
\hline 172 & Senegal & & & & \\
\hline 173 & Serbia and Montenegro & & & 2006 & 5 \\
\hline 174 & Serbia, Republic of & 2006 & 6 & & \\
\hline 175 & Seychelles & & & & \\
\hline 176 & Sierra Leone & & & & \\
\hline 177 & Singapore & & & & \\
\hline 178 & Sint Maarten & 2007 & 8 & & \\
\hline 179 & Slovak Republic & 1993 & 1 & & \\
\hline 180 & Slovenia & 1993 & 1 & & \\
\hline 181 & Solomon Islands & & & & \\
\hline 182 & Somalia & & & & \\
\hline 183 & South Africa & & & & \\
\hline 184 & South African Common Customs Area (SACCA) & & & 1997 & 12 \\
\hline 185 & South Sudan & 2011 & 7 & & \\
\hline 186 & Spain & & & & \\
\hline 187 & Special Categories & & & & \\
\hline 188 & Sri Lanka & & & & \\
\hline 189 & St. Kitts and Nevis & & & & \\
\hline 190 & St. Lucia & & & & \\
\hline 191 & St. Vincent and the Grenadines & & & & \\
\hline 192 & Sudan & & & & \\
\hline 193 & Suriname & & & & \\
\hline 194 & Swaziland & & & & \\
\hline 195 & Sweden & & & & \\
\hline 196 & Switzerland & & & & \\
\hline 197 & Syrian Arab Republic & & & & \\
\hline 198 & Taiwan Province of China & & & & \\
\hline 199 & Tajikistan & 1992 & 1 & & \\
\hline 200 & Tanzania & & & & \\
\hline 201 & Thailand & & & & \\
\hline
\end{tabular}




\begin{tabular}{|c|c|c|c|c|c|}
\hline N. & Country Name & $\begin{array}{l}\text { Start } \\
\text { Year }\end{array}$ & $\begin{array}{r}\text { Start } \\
\text { Month }\end{array}$ & $\begin{array}{l}\text { End } \\
\text { Year }\end{array}$ & $\begin{array}{r}\text { End } \\
\text { Month }\end{array}$ \\
\hline 202 & Timor-Leste, Dem. Rep. of & 2002 & 5 & & \\
\hline 203 & Togo & & & & \\
\hline 204 & Tonga & & & & \\
\hline 205 & Trinidad and Tobago & & & & \\
\hline 206 & Tunisia & & & & \\
\hline 207 & Turkey & & & & \\
\hline 208 & Turkmenistan & 1992 & 1 & & \\
\hline 209 & Tuvalu & & & & \\
\hline 210 & U.S.S.R. & & & 1991 & 12 \\
\hline 211 & Uganda & & & & \\
\hline 212 & Ukraine & 1992 & 1 & & \\
\hline 213 & United Arab Emirates & & & & \\
\hline 214 & United Kingdom & & & & \\
\hline 215 & United States & & & & \\
\hline 216 & Uruguay & & & & \\
\hline 217 & Uzbekistan & 1992 & 1 & & \\
\hline 218 & Vanuatu & & & & \\
\hline 219 & Vatican & & & & \\
\hline 220 & Venezuela, Republica Bolivariana de & & & & \\
\hline 221 & Vietnam & & & & \\
\hline 222 & West Bank and Gaza & & & & \\
\hline 223 & Western Hemisphere not specified & & & & \\
\hline 224 & Yemen Arab Rep. & & & 1990 & 5 \\
\hline 225 & Yemen, P.D. Rep. & & & 1990 & 5 \\
\hline 226 & Yemen, Republic of & 1990 & 6 & & \\
\hline 227 & Yugoslavia, SFR & & & 1993 & 12 \\
\hline 228 & Zambia & & & & \\
\hline 229 & Zimbabwe & & & & \\
\hline
\end{tabular}




\section{Annex 2. The Cholette-Dagum Benchmarking Method}

The benchmarking method proposed by Cholette and Dagum (2006) is based on a generalized least-squares regression model. It is a very flexible approach to adjust and make consistent data available at different frequencies (monthly, quarterly, and annual). The Cholette-Dagum method is one of the benchmarking methods recommended in the 2017 edition of the IMF's Quarterly National Accounts Manual (IMF, 2017).

Let $s_{t}$ indicate a preliminary monthly series, and $a_{m}$ benchmark values for the series $s_{t}$. The benchmarks $a_{m}$ can be available monthly, quarterly, or annually and can be observed on noncontiguous periods:

$$
\begin{gathered}
s_{t}, \quad t=1,2, \ldots, T \\
a_{m}, \quad m=1,2, \ldots, M
\end{gathered}
$$

Benchmarking is required to eliminate the discrepancies between the monthly series $S_{t}$ and the corresponding benchmarks $a_{m}$. If there are monthly benchmarks in $a_{m}$, the indicator $S_{t}$ will be adjust to be equal to the values of those benchmarks. For quarterly and annual benchmarks, the indicator series is adjusted so that the aggregation of corresponding monthly observations equals those benchmarks. Discrepancies $d_{m}$ between (1) and (2) are measured as:

$$
d_{m}=a_{m}-\sum_{t \in m} s_{t}
$$

where month $t$ is part of period $m$. These discrepancies can also be estimated in proportional terms:

$$
d_{m}^{p}=\frac{a_{m}}{\sum_{t \in m} s_{t}}
$$

The Cholette-Dagum model is made of two simultaneous equations: one for the highfrequency indicator, and one for the benchmarks. Both equations include the unknown benchmarked series $\theta_{t}$ as dependent variable:

$$
s_{t}=\sum_{h=1}^{H} r_{t, h} \beta_{h}+\theta_{t}+e_{t}, \quad t=1, \ldots, T
$$

where $E\left(e_{t}\right)=0, E\left(e_{t} e_{t-h}\right) \neq 0$, and

$$
a_{m}=\sum_{t=1, m}^{f, m} \theta_{t}+\varepsilon_{m}, \quad m=1, \ldots, M
$$


where $E\left(\varepsilon_{m}\right)=0, E\left(\varepsilon_{m}^{2}\right)=\sigma_{\varepsilon_{m}}^{2}, E\left(\varepsilon_{m} e_{t}\right)=0$. For simplicity, we assume binding benchmarks in equation (4). Therefore, $E\left(\varepsilon_{m}^{2}\right)=0$.

Equation (3) assumes that the indicator series $\left(s_{t}\right)$ deviates from the true unknown series $\theta_{t}$, while equation (4) ensures that these true unobserved values $\theta_{t}$ add up to the benchmarks $a_{m}$.

In equation (3), the deterministic regressors $\left(r_{t, h} \beta_{h}\right)$ can be defined simply as a constant effect to capture differences in scale between the indicator $s_{t}$ and the unknown series $\theta_{t}$. The error $e_{t}$ is the quarterly discrepancy. Because a key objective of benchmarking is to keep the movements in $\theta_{t}$ as close as possible to the movements in $s_{t}$, the error $e_{t}$ should have two characteristics:

- be proportional to the value of the indicator $s_{t}$. This property is necessary to distribute the errors proportionally to the level of the indicator;

- present smooth movements from one quarter to the next. A smooth distribution of $e_{t}$ makes the movements of $s_{t}$ and $\theta_{t}$ very close to each other.

To obtain a proportional adjustment, the error $e_{t}$ is standardized by the value of the indicator $S_{t}$, $e_{t}^{\prime}=\frac{e_{t}}{s_{t}}$

By doing so, the standard deviation of $e_{t}$ is assumed to be equal to $s_{t}$. To obtain a smooth distribution, the standardized error $e_{t}^{\prime}$ is assumed to follow a first-order (stationary) autoregressive model, or AR(1) model

$$
e_{t}^{\prime}=\phi e_{t-1}^{\prime}+v_{t}
$$

with $|\phi|<1$, where the $v_{t}$ 's are assumed to be independent and identically distributed innovations, that is

$$
E\left(v_{t}\right)=0, E\left(v_{t}^{2}\right)=1, E\left(v_{t}, v_{t-h}\right)=0 \text { for any } t \text { and } h \text {. }
$$

It can be shown that the Cholette-Dagum model with assumptions (6) and (7) minimizes the following objective function ${ }^{1}$

\footnotetext{
${ }^{1}$ Dagum and Cholette (2006, pp. 87-92)
} 
$\min _{\theta_{t}}\left\{\left(\frac{1}{1-\phi^{2}}\right)\left(\frac{\theta_{1}}{s_{1}}\right)^{2}+\sum_{t=2}^{q}\left[\frac{\theta_{t}}{s_{t}}-\phi \frac{\theta_{t-1}}{s_{t-1}}\right]^{2}\right\}$.

The AR parameter $\phi$ plays a crucial role in preserving the short-term dynamics of the indicator series. When $\phi$ is very close to 1 (e.g., 0.999) function (7) converges to the proportional Denton method. A value of $\phi$ lower than one should be used to adjust for a temporary bias in the indicator. For DOTS estimation, the value of $\phi$ is set to 0.9 .

Further details on the properties of the Cholette-Dagum method can be found in chapter 6 of the IMF's Quarterly National Accounts Manual (IMF, 2017). 